\title{
In Vivo Platelet Detection using a Glycoprotein IIb/IIIa-Targeted Near-Infrared Fluorescence Imaging Probe
}

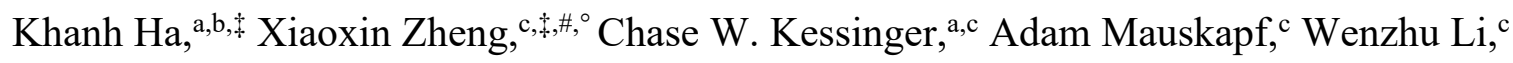

Makoto Orii, ${ }^{\mathrm{c}}$ Yoichiro Kawamura, ${ }^{\mathrm{c}}$ Scott A. Hilderbrand, ${ }^{\mathrm{b},}$ Farouc A. Jaffer,, ,d,,,\# Jason R. McCarthy,a,b,*,\#

${ }^{a}$ Masonic Medical Research Institute, Utica, New York, USA

${ }^{b}$ Center for Systems Biology, Massachusetts General Hospital, Harvard Medical School, Boston, Massachusetts, USA

${ }^{c}$ Cardiovascular Research Center, Cardiology Division, Massachusetts General Hospital, Harvard Medical School, Boston, Massachusetts, USA

${ }^{d}$ Wellman Center for Photomedicine, Massachusetts General Hospital, Harvard Medical School, Boston, Massachusetts, USA

*These authors contributed equally to this work.

*Shared senior authorship

${ }^{\#}$ Correspondence:

Jason R. McCarthy, Masonic Medical Research Institute, 2150 Bleecker Street, Utica, NY 13501,jmccarthy@mmri.edu, Tel. (315)624-7478, Fax. (315) 735-5648.

and

Farouc Jaffer, MGH CVRC, Simches Research Building, Room 3206, 185 Cambridge Street, Boston, MA 02114, fjaffer@mgh.harvard.edu, Tel. (617) 724-9353, Fax. (617) 643-3451. and

Xiaoxin Zheng, Department of Cardiology, Renmin Hospital of Wuhan University, 238 Jiefang Road, Wuhan, Hubei 430060, R.R. China, xiaoxinzheng@whu.edu.cn, Tel. +86 (027)88041911-82213, Fax. +86 (027)88041237.

Current address for Xiaoxin Zheng: Department of Cardiology, Renmin Hospital of Wuhan University, Cardiovascular Research Institute, Wuhan University, Hubei Key Laboratory of Cardiology, Wuhan, Hubei, China

^Current address for Scott A. Hilderbrand: Dyne Therapeutics, Waltham, Massachusetts, USASupporting Information Figure 3. Determination of optimal imaging time after the injection of TIRO-CyA15.5. 


\section{Supporting Information}

CyAl5.5 Fluorescence
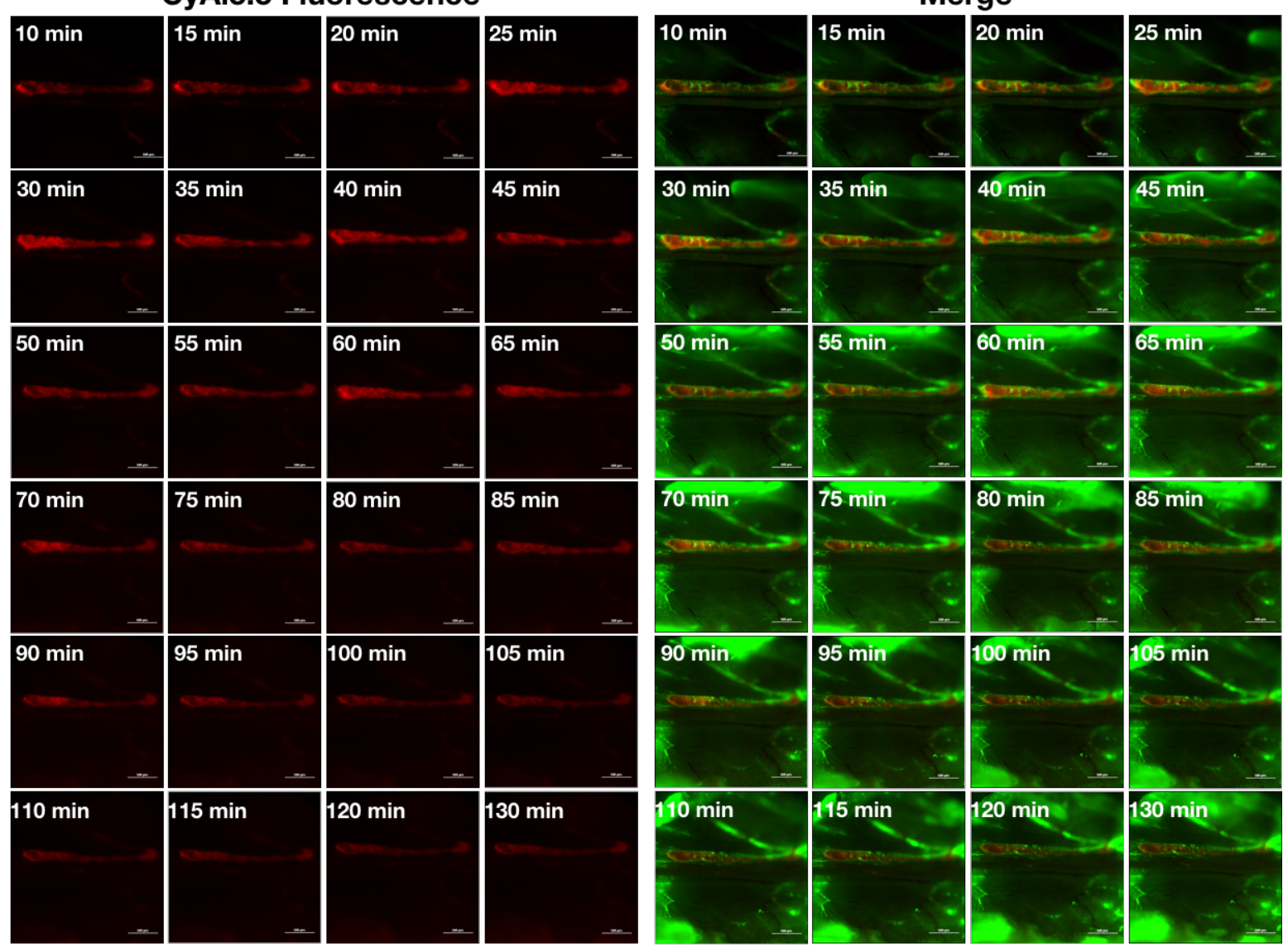

Fig. S1. Determination of optimal imaging time after the injection of TIRO-CyA15.5. The imaging probe was injected into femoral thrombus-bearing mice and imaged every 5 minutes to examine the kinetics of binding to determine the optimal imaging time point for subsequent experiments. From these experiments and the blood half-life determined in Figure S1, 30 minutes appears ideal based on a high NIRF platelet thrombus signal. The left panels depict the accumulation of TIRO-CyA15.5 within the thrombus (red pseudocolor), while the right panels are merged with vascular angiograms using fluorescein-labeled high molecular weight dextran (green pseudocolor). All images were windowed identically. 


\section{Supporting Information}

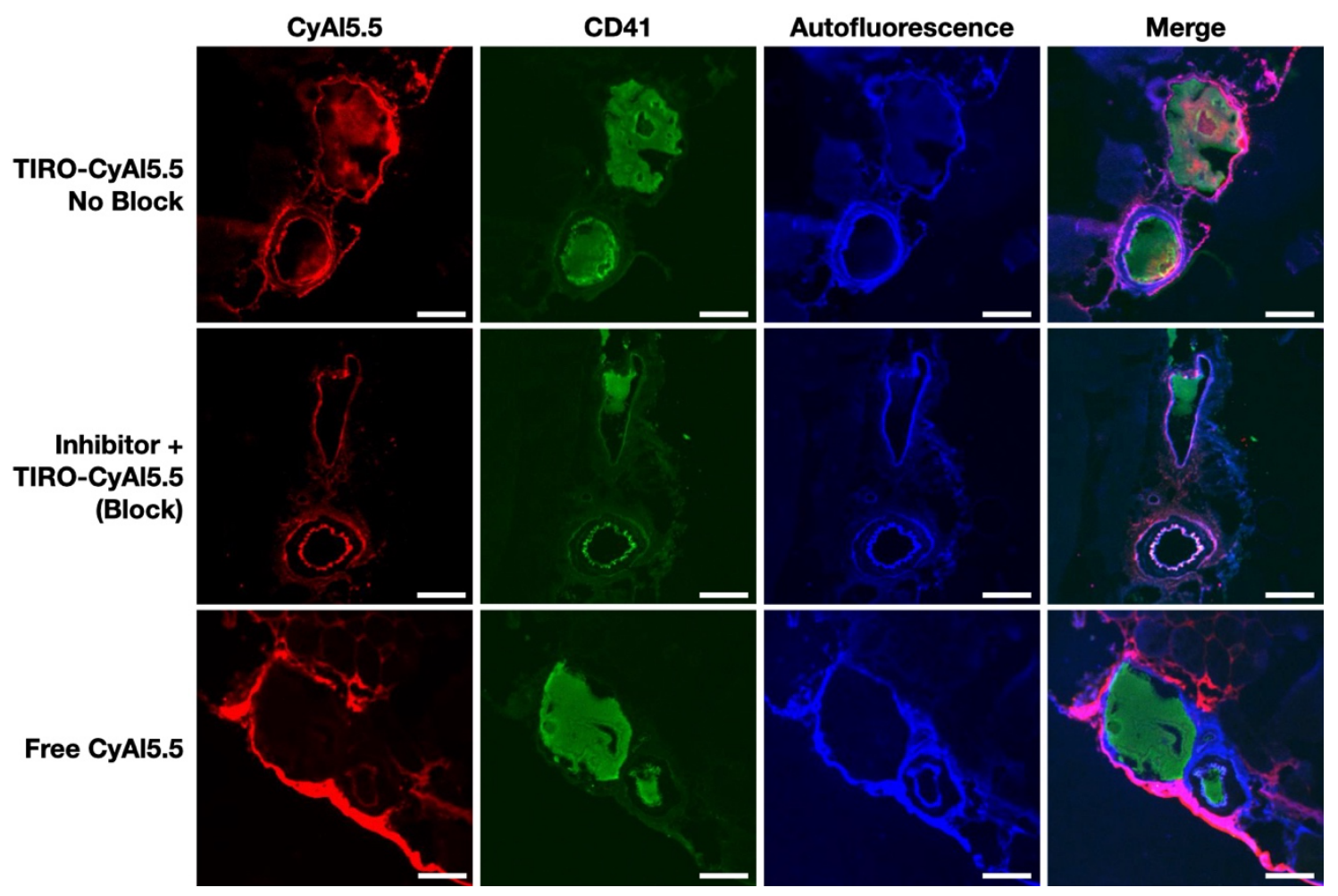

Fig. S2. Thrombus-specific binding of TIRO-CyA15.5 in murine ferric chloride-induced venous thrombi. Each group shows representative fluorescence microscopy. CyA15.5 (red), immunofluorescence (CD41, green), autofluorescence (blue), and merged image (CyA15.5+ CD41 + autofluorescence). Significant autofluorescence co-localized with the non-specific staining in the CyA15.5 channel. Tissue was resected 35 minutes after thrombus induction. Animal cohorts included mice receiving the imaging agent TIRO-CyAl5.5, a pre-block using the GPIIb/IIIa inhibitor (tirofiban) followed by injection of TIRO-CyA15.5, and a group receiving the free dye (CyA15.5). Scale bars $=100 \mu \mathrm{m}$. 


\section{Supporting Information}

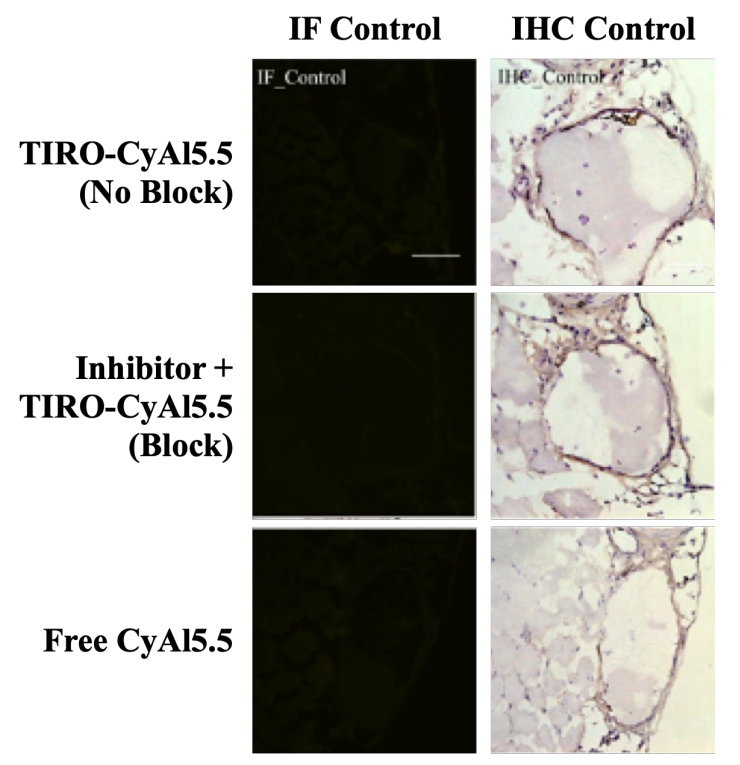

Figure S3. Immunofluorescence and immunohistochemistry control slides corresponding to the images in Figure 6. Primary antibody has been omitted in staining. Scale bars $=100 \mu \mathrm{m}$.

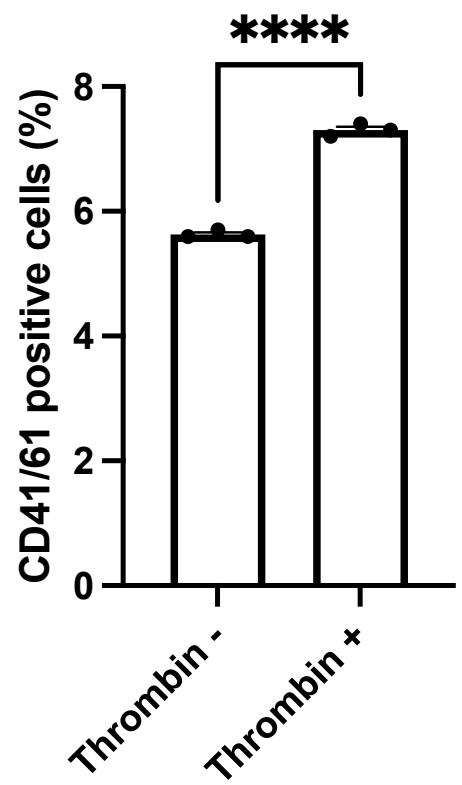

Fig. S4. Flow cytometric analysis of GPIIb/IIIa activation status. HEPES-buffered Tyrodewashed human platelets were incubated for 30 minutes with a FITC-labeled anti-CD41/61 antibody in the dark and then subject to flow cytometric analysis. $* * * * \mathrm{P}<0.0001$. 


\section{Supporting Information}

\section{Probe synthesis:}

General: Reagents were purchased from Sigma-Aldrich; deuterated solvents were from Cambridge Isotope Laboratories, Inc.; chemicals were used without further purification unless otherwise noted. Peptides were received on resin from the MGH Peptide/Protein Core Facility and were synthesized using Fmoc chemistries on rink amide resin. UV-vis spectra were recorded on a Varian Cary $50 \mathrm{UV}$-vis spectrophotometer (Palo Alto, CA, USA). Fluorescence data were collected with a Varian Cary Eclipse fluorescence spectrophotometer (Palo Alto, CA, USA). Silica gel (Sorbent Technologies, $60 \AA$, 40-63 $\mu \mathrm{m}, 230 \times 400$ mesh) was used for column chromatography.

Chemical characterization: ${ }^{1} \mathrm{H}$ and ${ }^{13} \mathrm{C}$ NMR spectra were recorded at $23^{\circ} \mathrm{C}$ on a Bruker Avance III $400 \mathrm{MHz}$ spectrometer. Chemical shifts were reported in parts per million $(\delta)$ and calibrated to the internal tetramethylsilane (TMS) standard or residual proton resonance and the natural abundance ${ }^{13} \mathrm{C}$ resonance of the solvent. Signal multiplicities are abbreviated as $\mathrm{s}$ (singlet), d (doublet), t (triplet), q (quartet), quint (quintet), m (multiplet), br (broad).

\section{High-performance liquid chromatography-mass spectrometry analysis (HPLC/MS):} HPLC/MS data were collected with a Waters 2695 high-performance liquid chromatography system (Milford, MA) equipped with a 2996 diode array detector, a Micromass ZQ4000 ESIMS module, and an Agilent Pursuit XRS5 $100 \times 2.0 \mathrm{~mm}$ column at a flow rate of $0.3 \mathrm{~mL} / \mathrm{min}$. Gradients were run with buffer $\mathrm{A}\left(\mathrm{H}_{2} \mathrm{O} / 0.1 \%\right.$ TFA) and buffer B (90\% acetonitrile/10\% $\mathrm{H}_{2} \mathrm{O} / 0.1 \%$ TFA)

Preparative HPLC: Reverse phase HPLC purifications were performed using an Agilent Technologies, Inc., Pursuit XRS $10 \mathrm{C} 18250$ x $21.2 \mathrm{~mm}$ column. UV detection was accomplished at both $650 \mathrm{~nm}$ and $254 \mathrm{~nm}$. A flow rate of $21 \mathrm{~mL} / \mathrm{min}$ was used for all 


\section{Supporting Information}

purifications. Gradients were run with buffer A $\left(\mathrm{H}_{2} \mathrm{O} / 0.1 \%\right.$ TFA) and buffer B (90\% acetonitrile/10\% $\mathrm{H}_{2} \mathrm{O} / 0.1 \%$ TFA) Elution gradients, as described below.

\section{Synthesis of CyAl5.5}

End group synthesis:

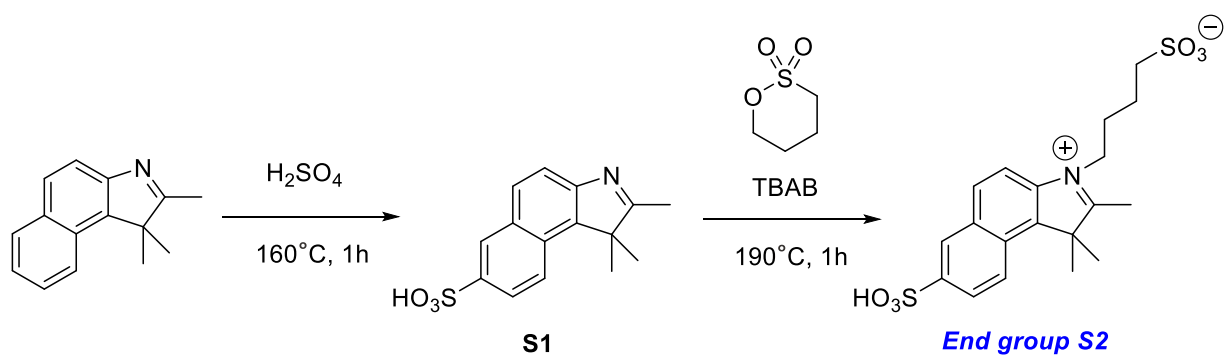

CyA15.5 synthesis:

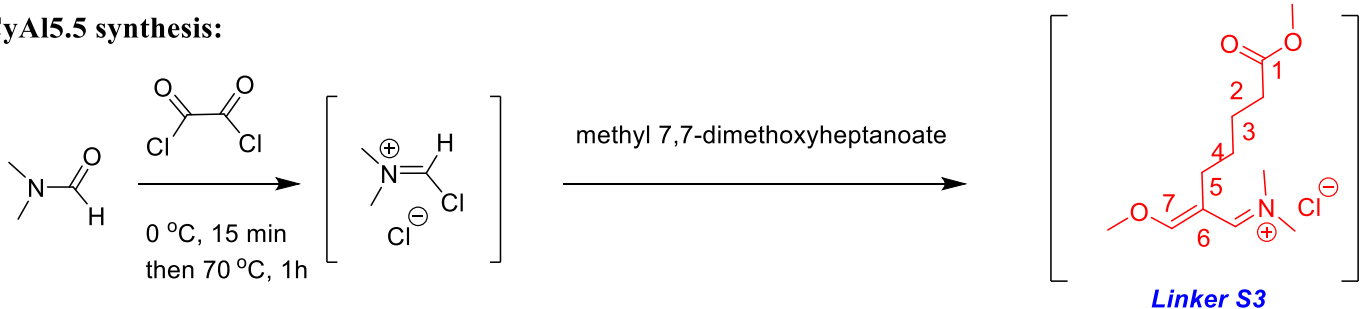

$\mathrm{AcOH}: \mathrm{Ac}_{2} \mathrm{O}: \mathrm{Et}_{3} \mathrm{~N}$ 5:5:1 End Group S2
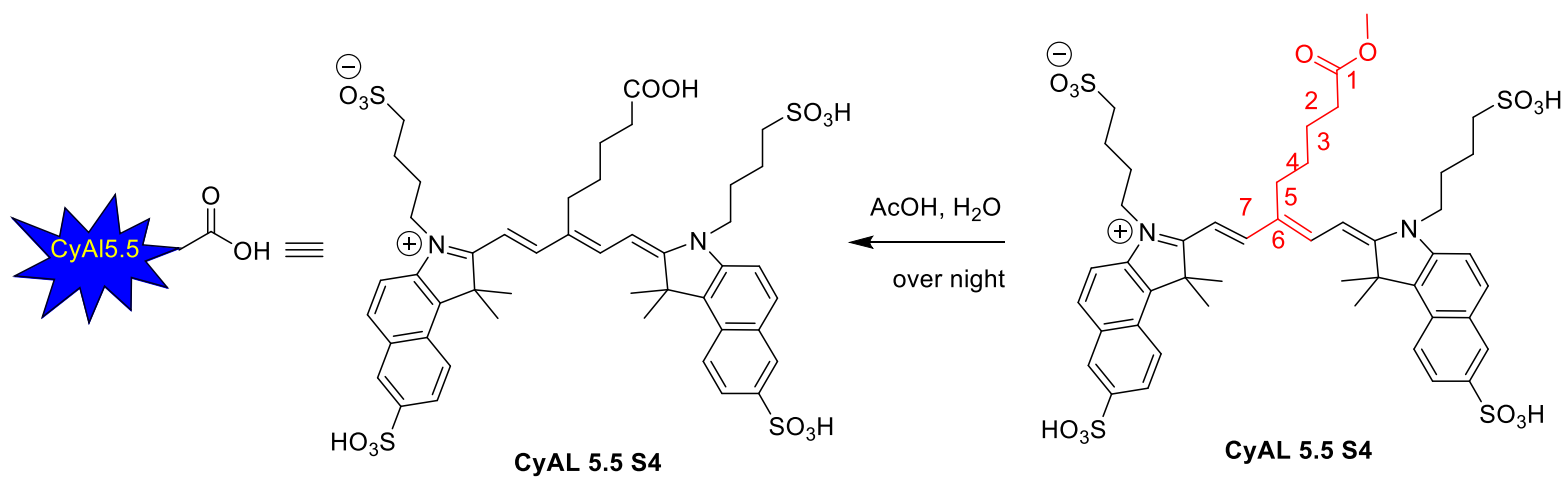

Scheme S1. Synthesis of CyA15.5 dye.

1,1,2-trimethyl-1H-benzo[e]indole-7-sulfonic acid, S1. To a $100 \mathrm{~mL}$ round bottom flask was added 1,1,2-trimethyl-1H-benz[e]indole $(8.37 \mathrm{~g}, 40 \mathrm{mmol})$ and sulfuric acid $(20 \mathrm{~mL})$. After stirring at $160^{\circ} \mathrm{C}$ for $1 \mathrm{~h}$, the reaction mixture was allowed to cool to room temperature, and ice-cold deionized water $(450 \mathrm{~mL})$ was added. The formed precipitate was isolated by filtration 


\section{Supporting Information}

and washed with ice-cold deionized water $(2 \times 80 \mathrm{~mL})$ and diethyl ether $(3 \times 120 \mathrm{~mL})$. The resulting paste was dried to get a pale brown solid (7.2g, 62\%). Compound $\mathbf{S 1}$ has been previously reported, with the proton NMR from this improved synthesis matching reported values. ${ }^{1}$

4-(1,1,2-trimethyl-7-sulfo-1H-benzo[e]indol-3-ium-3-yl)butane-1-sulfonate S2. 1,1,2trimethyl-1H-benzo[e]indole-7-sulfonic acid (2.28 g, 7.9 x 10-3 mol) and tetra-nbutylammonium bromide $(5.08 \mathrm{~g}, 1.5 \times 10-2 \mathrm{~mol})$ in butanesultone $(5 \mathrm{~mL})$ were stirred at $190^{\circ}$ $\mathrm{C}$ for $1 \mathrm{~h}$. The reaction mixture was allowed to cool to room temperature before the addition of acetone ( $150 \mathrm{~mL}$ in $25 \mathrm{~mL}$ portions) to affect precipitation. The precipitate was obtained by filtration. The isolated solid was then dissolved in deionized water $(12 \mathrm{~mL})$, precipitated with acetone $(350 \mathrm{~mL})$, and filtered to yield a light purple solid ( $3 \mathrm{~g}, 85 \%$ yield $)$, that was used as is in subsequent reactions. Compound $\mathbf{S} 2$ is also known, with a ${ }^{1} \mathrm{H}$ NMR matching reported values. ${ }^{1}$

Synthetic protocol for CyAl5.5 (S4). Into a heavy-walled pressure vessel containing oxalyl chloride (429 $\mu \mathrm{L}, 5$ mmol, 1 equiv) was carefully added to DMF ( $385 \mu \mathrm{L}, 5$ mmol, 1 equiv) at $0^{\circ} \mathrm{C}$ (on ice) over $15 \mathrm{~min}$ (Scheme S1). Methyl 7,7-dimethoxyheptanoate $(510 \mu \mathrm{L}$, $2.5 \mathrm{mml}, 0.5$ equiv ) was then added. The vessel was sealed and the reaction mixture was stirred at $70^{\circ} \mathrm{C}$ for $1 \mathrm{~h}$ and then allowed to cool to room temperature. The end group S2 $(2.15 \mathrm{~g}, 5$ $\mathrm{mmol})$ and a solution of acetic acid/acetic anhydride/triethylamine $(6.25 \mathrm{~mL} / 6.25 \mathrm{~mL} / 1.25 \mathrm{~mL})$ was then added to the vessel which was subsequently sealed and stirred at $160^{\circ} \mathrm{C}$ for $1 \mathrm{~h}$. The reaction mixture was allowed to cool to room temperature and then concentrated under vacuum. The residue was dissolved in $\mathrm{H}_{2} \mathrm{O}(50 \mathrm{~mL})$ and stirred at room temperature overnight. The crude product was purified by preparative HPLC (gradient: $80 \%$ buffer A to $60 \%$ buffer A, $30 \mathrm{~min}$ ), and all fractions containing the product combined and lyophilized, giving a dark blue-green solid (350 mg,15\% yield). UV-vis $\left(\mathrm{H}_{2} \mathrm{O}\right) \lambda_{\max }(\log \varepsilon): 677 \mathrm{~nm}(5.3)$; Fluorescence 


\section{Supporting Information}

$\left(\mathrm{H}_{2} \mathrm{O}\right) \lambda_{\max }\left(\phi_{\mathrm{Fl}}\right) 696 \mathrm{~nm}(0.12) .{ }^{1} \mathrm{H}$ NMR $\left(500 \mathrm{MHz}, \mathrm{DMSO}-d_{6}\right) \delta 8.27$ (br s, 2H), $8.23(\mathrm{~d}, J=$ $14.3 \mathrm{~Hz}, 2 \mathrm{H}), 8.20(\mathrm{~d}, J=8.9 \mathrm{~Hz}, 2 \mathrm{H}), 8.14(\mathrm{~d}, J=8.8 \mathrm{~Hz}, 2 \mathrm{H}), 7.86(\mathrm{~d}, J=8.7 \mathrm{~Hz}, 2 \mathrm{H}), 7.79$ $(\mathrm{d}, J=8.9 \mathrm{~Hz}, 2 \mathrm{H}), 6.26(\mathrm{~d}, J=14.2 \mathrm{~Hz}, 2 \mathrm{H}), 4.32(\mathrm{t}, J=7.4 \mathrm{~Hz}, 4 \mathrm{H}), 2.75-2.61(\mathrm{~m}, 6 \mathrm{H})$, $2.35(\mathrm{t}, J=7.1 \mathrm{~Hz}, 2 \mathrm{H}), 1.98(\mathrm{br} \mathrm{s}, 12 \mathrm{H}), 1.93-1.85(\mathrm{~m}, 4 \mathrm{H}), 1.84-1.74(\mathrm{q}, 4 \mathrm{H}), 1.78-1.72$ (m, 2H), $1.58-1.52(\mathrm{~m}, 2 \mathrm{H})$. 13C NMR (126 MHz, DMSO-d $) \delta 174.95,174.19,144.59$, $140.68,133.55,131.43,131.42,130.93,130.21,128.33,127.72,126.47,126.16,122.22$, $112.51,99.88,51.16,51.12,43.92,38.00,34.12,27.08,26.63,25.26,22.67$. Yield, $0.60 \mathrm{~g}$, 29\%. LRMS-ESI $[\mathrm{M}]^{+} \mathrm{m} / \mathrm{z}$ calcd. for $\left[\mathrm{C}_{46} \mathrm{H}_{54} \mathrm{~N}_{2} \mathrm{O}_{14} \mathrm{~S}_{4}\right]^{+}$986.2, found 986.2.
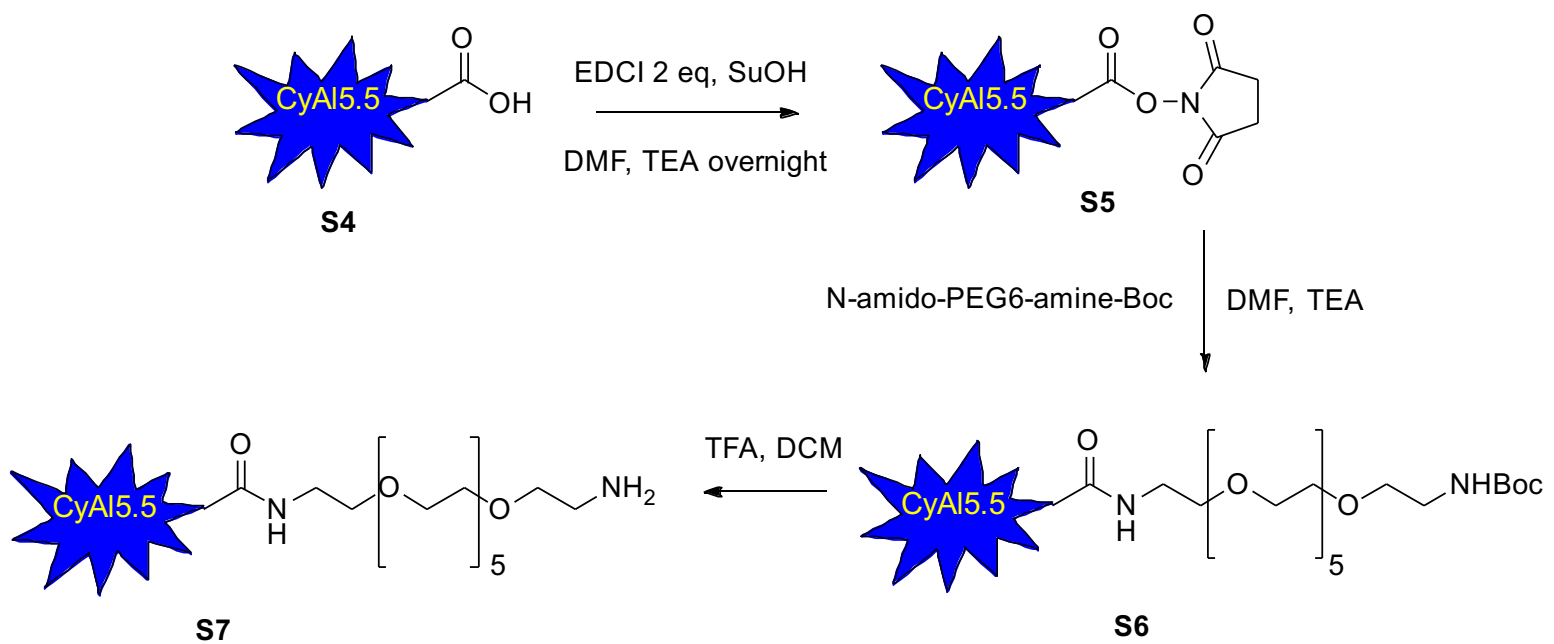

Scheme S2. Synthesis of CyA15.5-N-amido-PEG 6 -amine.

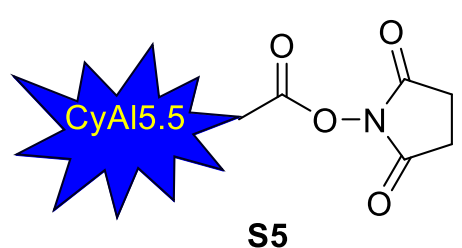

Synthesis of CyAl5.5-OSu (S5). N-(3-Dimethylaminopropyl)N'-ethyl carbodiimide hydrochloride (EDCI) (191 mg, $1 \mathrm{mmol})$ was added to a stirred solution of CyA15.5 (493 $\mathrm{mg}, 0.5 \mathrm{mmol})$ and N-hydroxysuccinimide (HOSu, $115 \mathrm{mg}, 1 \mathrm{mmol}$ ) dissolved in $50 \mathrm{~mL}$ N,Ndimethylformamide (DMF) at $0{ }^{\circ} \mathrm{C}$ under an argon atmosphere. The reaction was allowed to proceed for $1 \mathrm{~h}$ at $0{ }^{\circ} \mathrm{C}$, and was subsequently reacted for an additional $16 \mathrm{~h}$ at room temperature. DMF was removed under vacuum, with the residue being dissolved in buffer A and purified by HPLC (gradient: $80 \%$ buffer A to $60 \%$ buffer A, $30 \mathrm{~min}$ ) to afford CyA15.5- 


\section{Supporting Information}

OSu (S5) as a dark blue solid. Yield, $493 \mathrm{mg}$, 91\%. LRMS-ESI $[\mathrm{M}]^{+} \mathrm{m} / \mathrm{z}$ calcd. for $\left[\mathrm{C}_{50} \mathrm{H}_{57} \mathrm{~N}_{3} \mathrm{O}_{16} \mathrm{~S}_{4}\right]^{+}$1083.3, found 1083.3. ${ }^{3}$

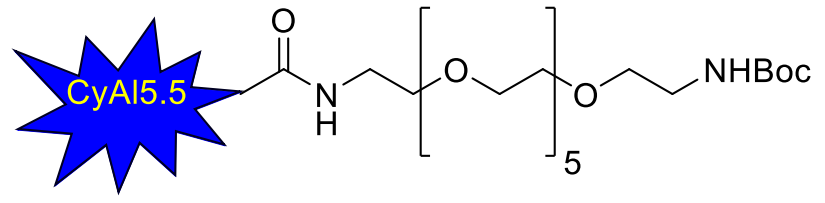

S6

\section{Synthesis of CyAl5.5-N-amido-PEG 6 -} amine-Boc (S6). CyAl5.5-OSu (541.5 mg, 0.5 mmol, 1 eq.) was dissolved in

anhydrous DMF $(15 \mathrm{~mL})$ and added dropwise to a stirred solution of amino-PEG 6 -amine-Boc (233 mg, $0.55 \mathrm{mmol}, 1.1$ eq.) and N,N-diisopropylethylamine (0.1 mL, DIPEA, $0.6 \mathrm{mmol}, 1.1$ eq.) in anhydrous DMF ( $1 \mathrm{~mL})$ which was cooled to $0{ }^{\circ} \mathrm{C}$. The reaction was carried out under an argon atmosphere at $0{ }^{\circ} \mathrm{C}$ for 2 hours, at which point it was allowed to warm to room temperature and stir for an additional $16 \mathrm{~h}$. The solvent was removed under vacuum, with the residue subsequently dissolved in $10 \mathrm{ml}$ of buffer A and purified by HPLC (gradient: 80\% buffer A to $60 \%$ buffer A, $30 \mathrm{~min}$ ) to afford CyAL-5.5-amido-PEG 6 -amine-Boc (S6) as a dark blue sticky solid. Yield, $918 \mathrm{mg}, 95 \%$. LRMS-ESI $[\mathrm{M}+\mathrm{H}]^{+} \mathrm{m} / \mathrm{z}$ calcd. for $\left[\mathrm{C}_{65} \mathrm{H}_{93} \mathrm{~N}_{4} \mathrm{O}_{21} \mathrm{~S}_{4}\right]^{+}$ 1393.5, found 1393.6.

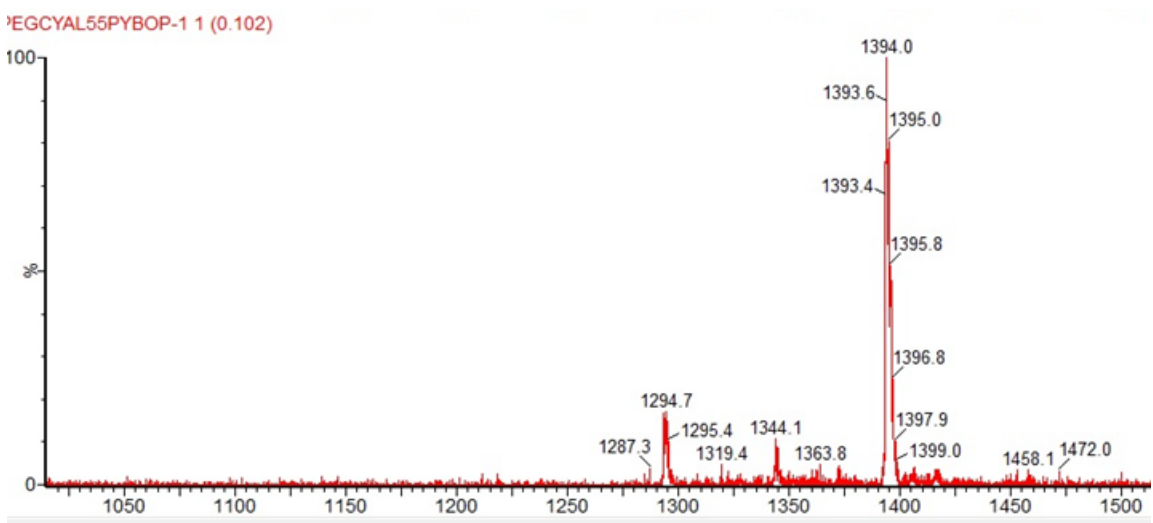

Figure S5. ESI-MS of CyA15.5-N-amido-PEG6-amine-Boc (S6) 


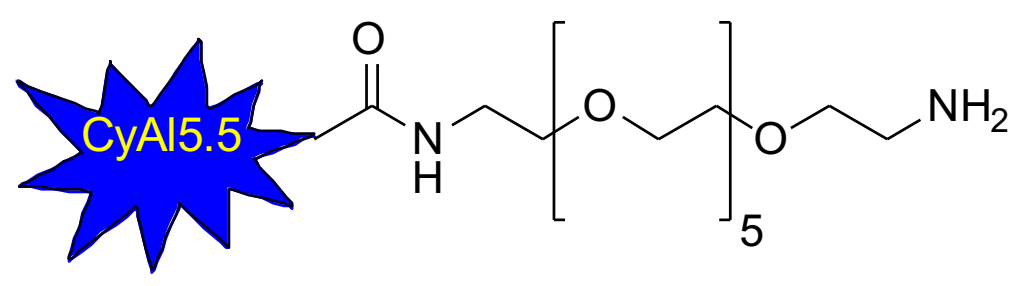

S7
Synthesis of CyAl5.5-N-

amido-PEG6-amine

(S7).

CyA15.5-N-amido-PEG6amine-Boc (697 mg, $0.5 \mathrm{mmol})$ was dissolved in anhydrous dichloromethane $(\mathrm{DCM}, 30 \mathrm{~mL})$ and trifluoroacetic $(3 \mathrm{~mL})$ at 0 ${ }^{\circ} \mathrm{C}$. The reaction was carried out under an argon atmosphere and proceeded for 2 hours. DCM and TFA were removed under vacuum, and the residue was then dissolved in $3 \mathrm{ml}$ of buffer $\mathrm{A}$ and purified by HPLC (gradient: $80 \%$ buffer A to $60 \%$ buffer A, $30 \mathrm{~min}$ ) to afford CyA15.5amido-PEG 6 -amine (10) as a dark blue sticky solid. Yield, $633 \mathrm{mg}, 98 \%$. LRMS-ESI $[\mathrm{M}+\mathrm{H}]^{+}$ $\mathrm{m} / \mathrm{z}$ calcd. for $\left[\mathrm{C}_{60} \mathrm{H}_{85} \mathrm{~N}_{4} \mathrm{O}_{19} \mathrm{~S}_{4}\right]^{+} 1293.5$, found 1293.9

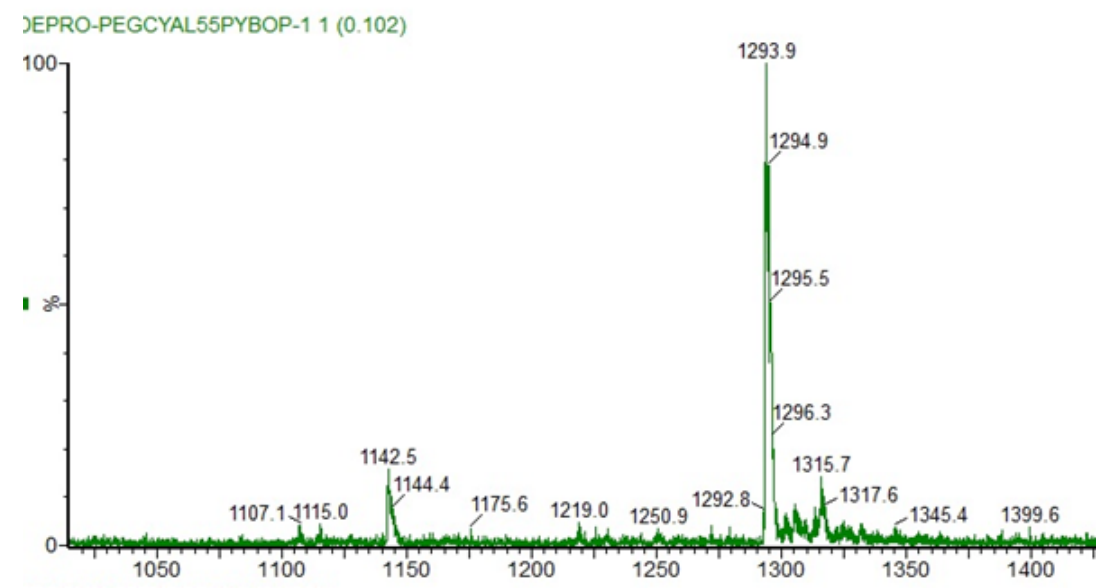

Figure S6. ESI-MS of CyAl5.5-N-amido-PEG6-amine (S7) 


\section{Supporting Information}

The synthesis procedure of tirofiban derivative (5):
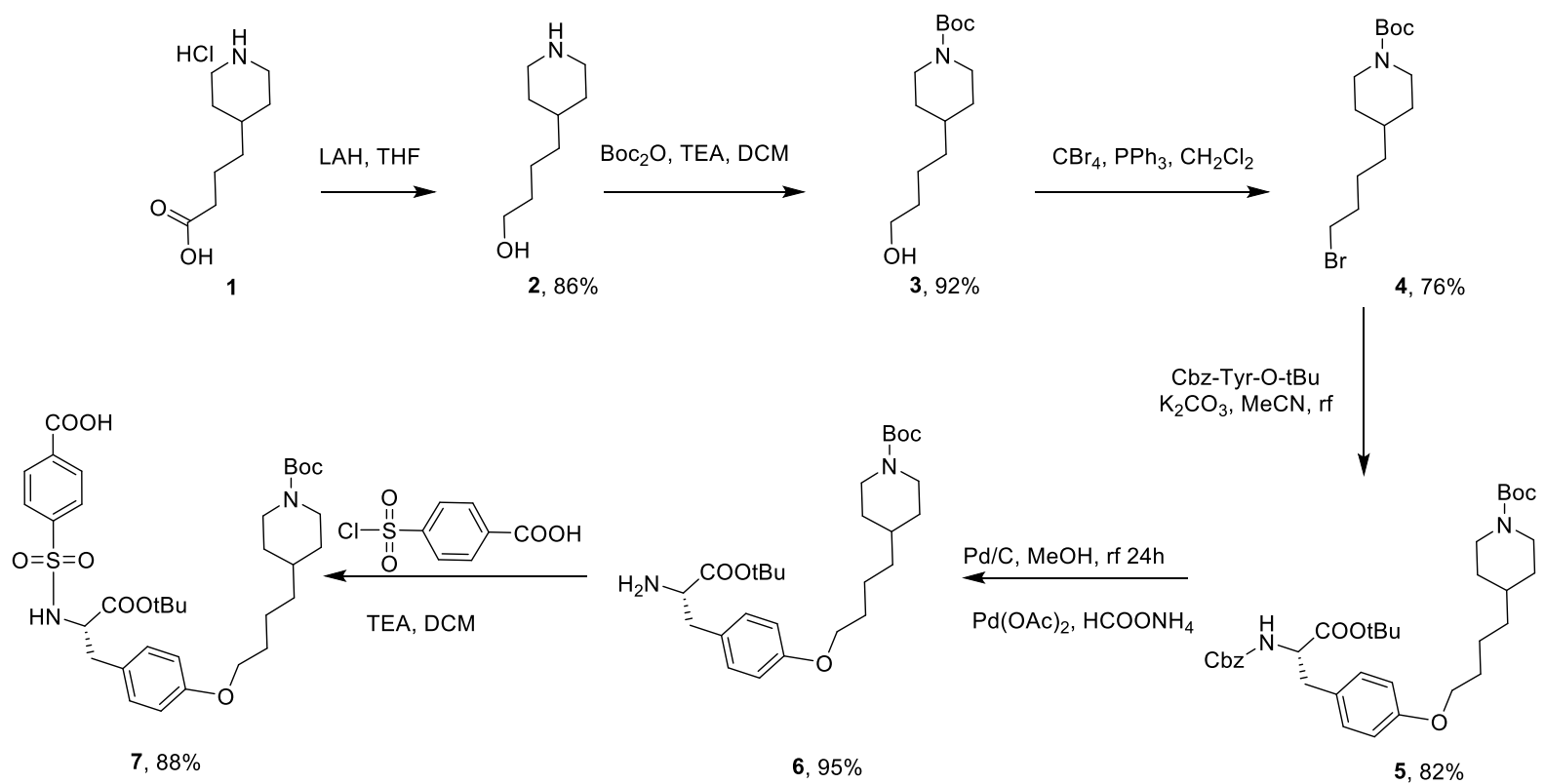

Scheme S3. Synthesis of Boc protected Tirofiban analog

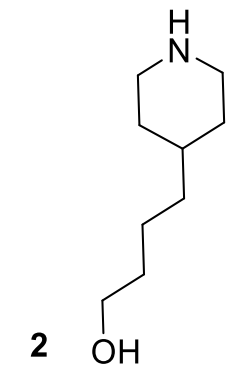

Procedures for preparation of 4-(Piperidin-4-yl)butan-1-ol (2). Under an atmosphere of argon, piperidine derivative 1 (400 mg, 2 mmol) was suspended in anhydrous THF $(15 \mathrm{~mL})$, and the mixture was cooled down in an ice-bath. $\mathrm{LiAlH}_{4}(365 \mathrm{mg}, 4.8 \mathrm{mmol})$ was added dropwise over a period of $10 \mathrm{~min}$. The resulting suspension was stirred at $0{ }^{\circ} \mathrm{C}$ for $1 \mathrm{~h}$ and under reflux for $12 \mathrm{~h}$. The mixture was cooled to $\mathrm{rt}$, and a $20 \%$ aq $\mathrm{NaOH}$ solution $(\mathrm{w} / \mathrm{w}, 10 \mathrm{~mL})$ was added, with the resulting suspension vigorously stirred for $1 \mathrm{~h}$. The solid material was removed by filtration through a pad of Celite, and the volatiles of the filtrate were removed under reduced pressure to yield product 2 as a pale-yellow oil $(258 \mathrm{mg}, 1.6 \mathrm{mmol}, 86 \%)$, which was used without purification. Compound $\mathbf{2}$ is known with a ${ }^{1} \mathrm{H}$ NMR matching previously reported values (for carbon NMR, please see ref. $\left.\mathrm{N}^{\circ} 5\right) .{ }^{1} \mathrm{H}$ NMR (400 MHz, Chloroform- $d$ ) $\delta 3.68(\mathrm{t}, J=6.4 \mathrm{~Hz}, 1 \mathrm{H}), 3.53(\mathrm{t}, J$ $=6.6 \mathrm{~Hz}, 2 \mathrm{H}), 3.06-2.98(\mathrm{~m}, 2 \mathrm{H}), 2.52(\mathrm{td}, J=12.4,2.9 \mathrm{~Hz}, 2 \mathrm{H}), 1.82-1.74(\mathrm{~m}, 1 \mathrm{H}), 1.67$ $-1.57(\mathrm{~m}, 2 \mathrm{H}), 1.47(\mathrm{p}, J=6.9 \mathrm{~Hz}, 2 \mathrm{H}), 1.29(\mathrm{dq}, J=10.2,6.8,5.8 \mathrm{~Hz}, 2 \mathrm{H}), 1.18(\mathrm{dt}, J=12.3$, $6.6 \mathrm{~Hz}, 2 \mathrm{H}), 1.07(\mathrm{qd}, J=12.3,4.2 \mathrm{~Hz}, 2 \mathrm{H}) . \mathrm{LRMS}(\mathrm{ESI}): \mathrm{m} / \mathrm{z}[\mathrm{M}+\mathrm{H}]^{+}$calcd for $\left[\mathrm{C}_{9} \mathrm{H}_{20} \mathrm{NO}\right]^{+}$ 


\section{Supporting Information}

158.15, found 158.15 .

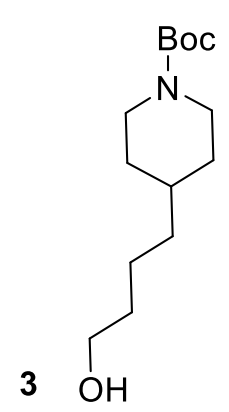

Synthesis of tert-Butyl 4-(4-hydroxybutyl)piperidine-1-carboxylate (3). To

a solution of 2 (204 mg, $1.29 \mathrm{mmol})$ and 4-dimethylaminopyridine (237 mg, $1.94 \mathrm{mmol})$ in methylene chloride $(15 \mathrm{~mL})$ at $0{ }^{\circ} \mathrm{C}$ was added triethylamine (0.36 mL, $2.58 \mathrm{mmol})$ and di-tert-butyldicarbonate (564 $\mathrm{mg}, 2.58 \mathrm{mmol})$, and the reaction was warmed to room temperature and stirred for $6 \mathrm{~h}$. After dilution with saturated ammonium chloride and extraction with ethyl acetate $(3 \times 30 \mathrm{~mL})$, the combined organics were concentrated in vacuo. Flash chromatography $(1: 10$ methanol/methylene chloride) gave product $\mathbf{3}$ as a colorless oil (305 mg, 92\%). Compound $\mathbf{3}$ also is known and has a ${ }^{1} \mathrm{H}$ NMR matching reported values (for carbon NMR, please see ref. $\left.\mathrm{N}^{\circ} 5\right) .{ }^{1} \mathrm{H}$ NMR (400 MHz, Methanol- $\left.d_{4}\right) \delta 4.04(\mathrm{~d}, J=13.1 \mathrm{~Hz}, 2 \mathrm{H}), 3.54(\mathrm{t}, J=6.5 \mathrm{~Hz}, 2 \mathrm{H})$, $2.78-2.62(\mathrm{~m}, 2 \mathrm{H}), 1.69(\mathrm{~d}, J=13.8 \mathrm{~Hz}, 2 \mathrm{H}), 1.56-1.42(\mathrm{~m}, 3 \mathrm{H}), 1.44(\mathrm{~s}, 9 \mathrm{H}), 1.42-1.32$ (m, 2H), $1.31-1.23(\mathrm{~m}, 2 \mathrm{H}), 1.03(\mathrm{qd}, J=12.4,4.1 \mathrm{~Hz}, 2 \mathrm{H}) . \mathrm{LRMS}(\mathrm{ESI}): \mathrm{m} / \mathrm{z}[\mathrm{M}+\mathrm{H}]^{+}$calcd. for $\left[\mathrm{C}_{14} \mathrm{H}_{28} \mathrm{NO}_{3}\right]^{+} 258.21$, found: 258.22

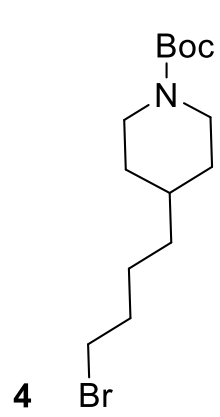

Synthesis procedure of tert-butyl 4-(4-bromobutyl)piperidine-1carboxylate (4). Alcohol 3 (404 mg, $1.57 \mathrm{mmol})$ and $\mathrm{PPh}_{3}(1.2 \mathrm{~g}, 4.57 \mathrm{mmol})$ were dissolved in $\mathrm{CH}_{2} \mathrm{Cl}_{2}(30 \mathrm{~mL})$, and the solution was cooled to $-5^{\circ} \mathrm{C}(\mathrm{NaCl}$ ice bath) under an atmosphere of argon. A solution of $\mathrm{CBr}_{4}(3.4 \mathrm{~g}, 10.25 \mathrm{mmol})$ in $\mathrm{CH}_{2} \mathrm{Cl}_{2}(20 \mathrm{~mL})$ was slowly dropped into the stirred mixture, thereby keeping the temperature of the mixture below $5^{\circ} \mathrm{C}$. After completed addition, stirring was continued at room temperature for $24 \mathrm{~h}$. The solvent was removed under reduced pressure to give a brown residue, which was subjected to flash chromatography (eluent: light petroleum/acetone $/ 25 \%$ aq $\left.\mathrm{NH}_{3} 85: 15: 1 \mathrm{v} / \mathrm{v} / \mathrm{v}\right)$ to afford compound 3 as a brown oil (250 mg, 50\%). Compound 4 is known. The ${ }^{1} \mathrm{H}$ NMR matches with reported values (for carbon NMR, please see ref. $\mathrm{N}^{\circ} 5$ ). ${ }^{1} \mathrm{H}$ NMR $(400 \mathrm{MHz}$, Chloroform- $d$ ) $\delta 4.00$ (br s, 2H), $3.34(\mathrm{t}, J=6.7 \mathrm{~Hz}, 2 \mathrm{H}), 2.60(\mathrm{t}, J=12.9 \mathrm{~Hz}, 2 \mathrm{H})$, 


\section{Supporting Information}

$1.78(\mathrm{p}, J=7.0 \mathrm{~Hz}, 2 \mathrm{H}), 1.64-1.55(\mathrm{~m}, 2 \mathrm{H}), 1.52-1.49(\mathrm{~m}, 2 \mathrm{H}), 1.38$ (br s, 9H), 1.31 (ddd, $J=10.9,7.3,3.8 \mathrm{~Hz}, 1 \mathrm{H}), 1.22-1.13(\mathrm{~m}, 2 \mathrm{H}), 1.01(\mathrm{qd}, J=12.4,4.4 \mathrm{~Hz}, 2 \mathrm{H})$. LRMS (ESI): $\mathrm{m} / \mathrm{z}[\mathrm{M}+\mathrm{H}]^{+}$calcd. for $\left[\mathrm{C}_{14} \mathrm{H}_{27} \mathrm{BrNO}_{2}\right]^{+} 320.12$, found: 320.15

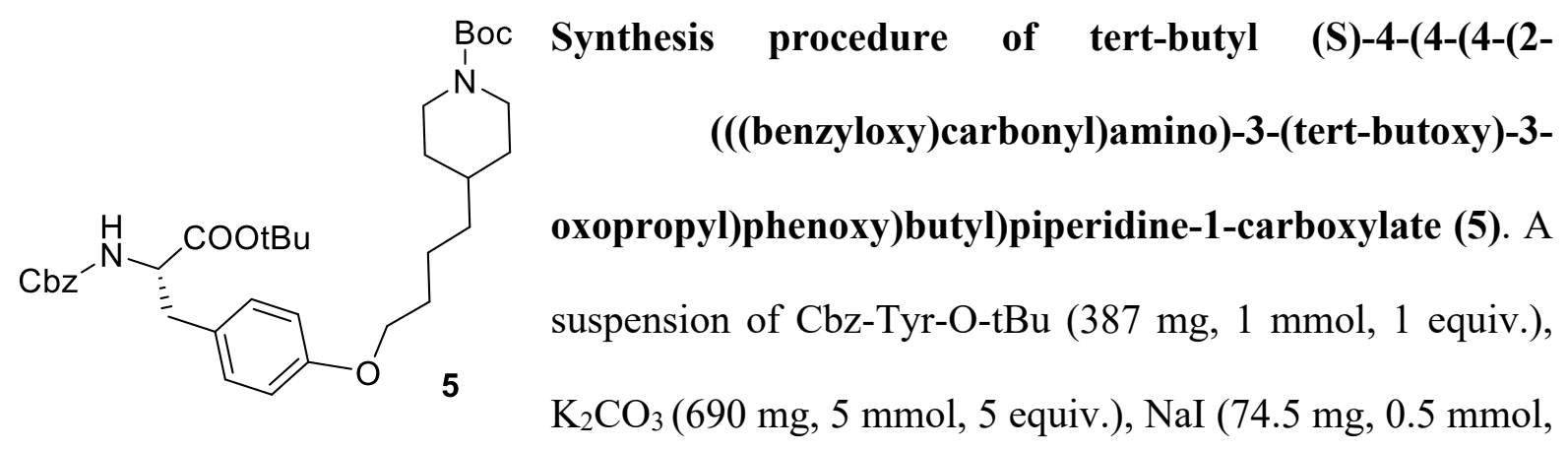

0.5 equiv.) and tert-butyl 4-(4-bromobutyl)piperidine-1-carboxylate (4) $(320 \mathrm{mg}, 1 \mathrm{mmol}, 1$ equiv.) in $\mathrm{MeCN}(200 \mathrm{~mL}$ ) were refluxed for $24 \mathrm{~h}$. After being cooled to room temperature, the reaction mixture was poured into water, extracted with EtOAc $(4 \times 75 \mathrm{~mL})$ and washed with brine $(2 \times 50 \mathrm{~mL})$. The combined organic layers were dried over anhydrous $\mathrm{MgSO}_{4}$, filtered to remove the solid, and evaporated to dryness. The crude products were purified by flash column chromatography on silica with n-hexanes/EtOAc (15:1) to give $\mathbf{5}$ as yellow oil (518 mg, $0.86 \mathrm{mmol}, 86 \%) .{ }^{1} \mathrm{H}$ NMR (500 MHz, Methanol- $\left.d_{4}\right) \delta 7.48-7.25(\mathrm{~m}, 5 \mathrm{H}), 7.13(\mathrm{~d}$, $J=8.6 \mathrm{~Hz}, 2 \mathrm{H}), 6.83(\mathrm{~d}, J=8.6 \mathrm{~Hz}, 2 \mathrm{H}), 5.17-4.98(\mathrm{~m}, 2 \mathrm{H}), 4.28(\mathrm{dd}, J=8.7,6.2 \mathrm{~Hz}, 1 \mathrm{H})$, $4.06(\mathrm{dt}, J=13.4,3.0 \mathrm{~Hz}, 2 \mathrm{H}), 3.97(\mathrm{t}, J=6.3 \mathrm{~Hz}, 2 \mathrm{H}), 3.02(\mathrm{dd}, J=13.8,6.2 \mathrm{~Hz}, 1 \mathrm{H}), 2.87(\mathrm{dd}$, $J=13.8,8.7 \mathrm{~Hz}, 1 \mathrm{H}), 2.78-2.62(\mathrm{~m}, 2 \mathrm{H}), 1.77(\mathrm{dt}, J=14.3,6.7 \mathrm{~Hz}, 2 \mathrm{H}), 1.77-1.64(\mathrm{~m}, 2 \mathrm{H})$, $1.62-1.48(\mathrm{~m}, 2 \mathrm{H}), 1.47(\mathrm{~s}, 9 \mathrm{H}), 1.42(\mathrm{~s}, 9 \mathrm{H}), 1.38-1.24(\mathrm{~m}, 3 \mathrm{H}), 1.07(\mathrm{qd}, J=12.5,4.3 \mathrm{~Hz}$, 2H). ${ }^{13} \mathrm{C}$ NMR (126 MHz, MeOD) $\delta 171.49,156.79,156.00,155.14,136.80,130.15,128.16$, $127.92,127.66,127.47,114.97,114.23,81.48,79.45,67.55,66.22,60.24,56.39,36.80,36.03$, $35.67,31.97,29.25,27.65,27.08,22.90,19.78,13.37$. LRMS (ESI): $\mathrm{m} / \mathrm{z}[\mathrm{M}+\mathrm{Na}]^{+}$calcd for $\left[\mathrm{C}_{35} \mathrm{H}_{50} \mathrm{~N}_{2} \mathrm{O}_{7} \mathrm{Na}\right]^{+}$633.35, found 633.36., 


\section{Supporting Information}

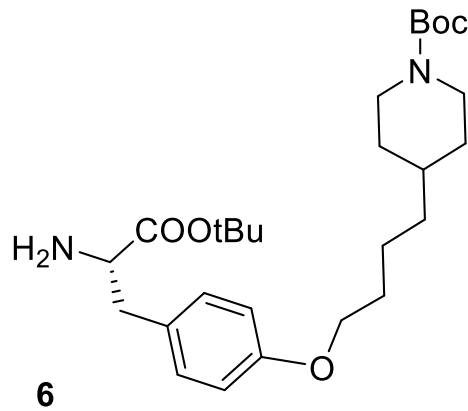

Synthesis procedure of tert-butyl (S)-4-(4-(4-(2-amino-3(tert-butoxy)-3-oxopropyl)phenoxy)butyl)piperidine-1carboxylate (6). tert-butyl (S)-4-(4-(4-(2(((benzyloxy)carbonyl)amino)-3-(tert-butoxy)-3oxopropyl)phenoxy)butyl)piperidine-1-carboxylate (5)

(1.7 g, 2.8 mmol, 1 e equiv.) was dissolved in $\mathrm{MeOH}(20 \mathrm{~mL})$. To the solution was added $\mathrm{Pd} / \mathrm{C}(10 \%, 150 \mathrm{mg}), \mathrm{Pd}(\mathrm{OAc})_{2}(235 \mathrm{mg}, 0.42 \mathrm{mmol} 15 \mathrm{~mol} \%)$, and ammonium formate (882 $\mathrm{mg}, 14 \mathrm{mmol}, 5$ equiv.) in a round-bottomed flask. The atmosphere in the flask was replaced with hydrogen using a balloon filled with the gas, and the reaction was allowed to proceed for $3 \mathrm{~h}$ under hydrogen atmosphere while refluxing. Over the course of the reaction, a white precipitate was formed which was subsequently dissolved by the addition of methanol. The $\mathrm{Pd} / \mathrm{C}$ was removed by filtration through Celite. The filtrate was concentrated under reduced pressure. The crude product was dissolved in EtOAc $(100 \mathrm{~mL})$ and washed with brine $(2 \times 50$ $\mathrm{mL})$ and $\mathrm{HCl}(2 \times 20 \mathrm{~mL})$. The combined organic layers were dried over anhydrous $\mathrm{MgSO}_{4}$, filtered to remove the drying agent, concentrated, and the crude products were purified by flash column chromatography on silica gel with $n$-hexanes/EtOAc $(15: 1)$ to give products $\mathbf{6}$ as yellow oil (1.27 g, $2.66 \mathrm{mmol}, 95 \%) .{ }^{1} \mathrm{H}$ NMR (400 MHz, Methanol- $\left.d_{4}\right) \delta 7.11(\mathrm{~d}, J=8.2 \mathrm{~Hz}$, 2H), $6.83(\mathrm{~d}, J=8.2 \mathrm{~Hz}, 2 \mathrm{H}), 4.04(\mathrm{~d}, J=13.1 \mathrm{~Hz}, 2 \mathrm{H}), 3.95(\mathrm{t}, J=6.2 \mathrm{~Hz}, 2 \mathrm{H}), 3.54(\mathrm{t}, J=$ $6.7 \mathrm{~Hz}, 1 \mathrm{H}), 2.94-2.82(\mathrm{~m}, 2 \mathrm{H}), 2.76-2.68(\mathrm{~m}, 2 \mathrm{H}), 1.78-1.64(\mathrm{~m}, 4 \mathrm{H}), 1.54-1.44(\mathrm{~m}$, 4H), 1.44 (s, 9H), 1.39 (s, 9H), $1.34-1.27(\mathrm{~m}, 3 \mathrm{H}), 1.12-0.98(\mathrm{~m}, 2 \mathrm{H}) .{ }^{13} \mathrm{C}$ NMR (101 MHz, MeOD) $\delta 173.82,158.09,155.15,130.10,128.81,114.12,80.93,79.42,67.48,55.89,39.75$, 35.98, 35.70, 31.96, 29.14, 27.33, 26.87, 22.79. LRMS (ESI): $\mathrm{m} / \mathrm{z}[\mathrm{M}+\mathrm{H}]^{+}$calcd for $\left[\mathrm{C}_{27} \mathrm{H}_{45} \mathrm{~N}_{2} \mathrm{O}_{7}\right]^{+}$477.34, found $477.364 .^{6}$ 


\section{Supporting Information}

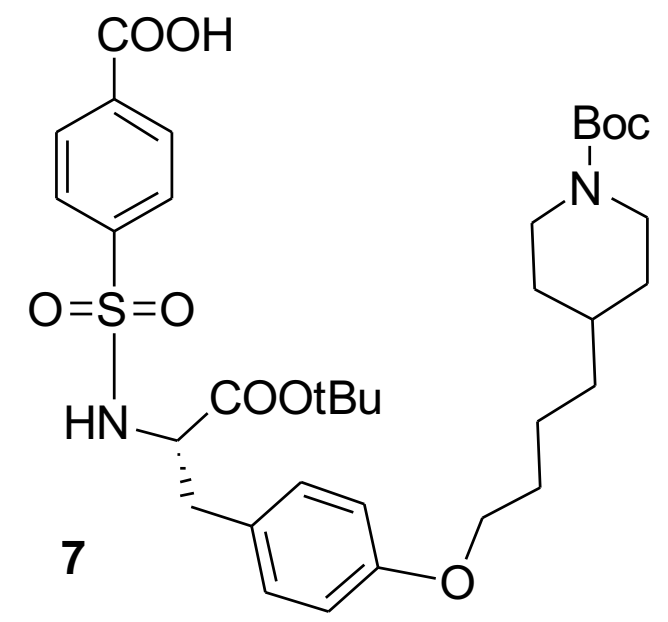

Procedures for preparation of (S)-4-(N-(1-(tert-

butoxy)-3-(4-(4-(1-(tertbutoxycarbonyl)piperidin-4-yl)butoxy)phenyl)-1oxopropan-2-yl)sulfamoyl)benzoic acid (7). To a solution of compound $6(238 \mathrm{mg}, 0.5 \mathrm{mmol})$ in dry dichloromethane $(10 \mathrm{~mL})$ at $0{ }^{\circ} \mathrm{C}$ was added triethylamine $(0.086 \mathrm{~mL}, 0.55 \mathrm{mmol})$ and $4-$

(chlorosulfonyl)benzoic acid $(110 \mathrm{mg}, 0.50 \mathrm{mmol})$. The reaction mixture was stirred at room temperature overnight. The reaction mixture was then diluted with dichloromethane $(75 \mathrm{~mL})$ and washed with brine $(2 \times 50 \mathrm{~mL})$ and $\mathrm{HCl}(2 \times 20 \mathrm{~mL})$. The solvent was removed under reduced pressure. The crude compound was purified by flash chromatography on silica gel, using ethyl acetate/hexane (3:5) as the eluent, to give product $7(105.42 \mathrm{mg}, 88 \%) .{ }^{1} \mathrm{H}$ NMR $\left(500 \mathrm{MHz}\right.$, Methanol- $\left.d_{4}\right) \delta 7.89(\mathrm{~d}, J=7.1 \mathrm{~Hz}, 2 \mathrm{H}), 7.80(\mathrm{~d}, J=8.5 \mathrm{~Hz}, 2 \mathrm{H}), 7.18(\mathrm{~d}, J=8.5$ $\mathrm{Hz}, 2 \mathrm{H}), 6.84(\mathrm{~d}, J=7.2 \mathrm{~Hz}, 2 \mathrm{H}), 4.73-4.61(\mathrm{~m}, 1 \mathrm{H}), 4.08-4.00(\mathrm{~m}, 2 \mathrm{H}), 3.94(\mathrm{dt}, J=7.8$, $5.6 \mathrm{~Hz}, 2 \mathrm{H}), 3.17(\mathrm{dd}, J=13.9,6.2 \mathrm{~Hz}, 1 \mathrm{H}), 3.05(\mathrm{dd}, J=8.8,5.1 \mathrm{~Hz}, 1 \mathrm{H}), 2.74-2.68(\mathrm{~m}$, 2H), $1.80-1.66(\mathrm{~m}, 4 \mathrm{H}), 1.53-1.50(\mathrm{~m}, 1 \mathrm{H}), 1.45(\mathrm{~s}, 9 \mathrm{H}), 1.44(\mathrm{~s}, 9 \mathrm{H}), 1.34-1.30(\mathrm{~m}, 2 \mathrm{H})$, $1.26-1.24(\mathrm{~m}, 4 \mathrm{H}) .{ }^{13} \mathrm{C}$ NMR (101 MHz, MeOD) $\delta 171.45,158.18,156.92,155.16,136.86$, $129.97,128.75,128.02,127.51,127.29,114.04,81.41,79.43,67.46,66.06,56.38,36.58$, 35.98, 35.70, 31.95, 29.14, 27.32, 26.80, 22.80. LRMS (ESI): calcd for: $\mathrm{C}_{34} \mathrm{H}_{49} \mathrm{~N}_{2} \mathrm{O}_{9} \mathrm{~S}[\mathrm{M}+\mathrm{H}]$ ${ }^{+}=661.32$, found $[\mathrm{M}+\mathrm{H}]^{+}=661.32$. 


\section{Supporting Information}

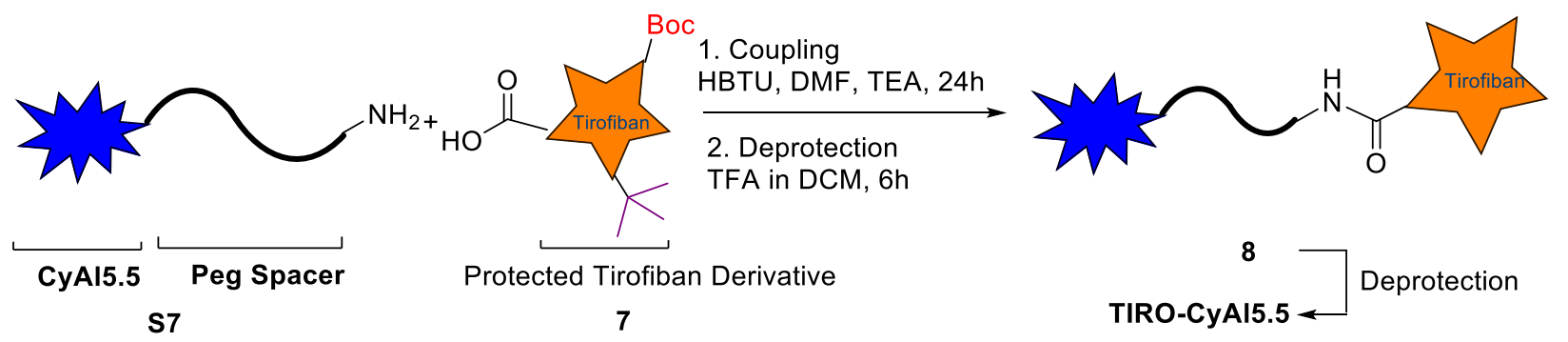<smiles>O=C(O)c1ccc(C[C@H](NS(=O)(=O)c2ccc(OCCCCC3CCN(C(=O)OCc4ccccc4)CC3)cc2)C(=O)OCc2ccccc2)cc1</smiles>

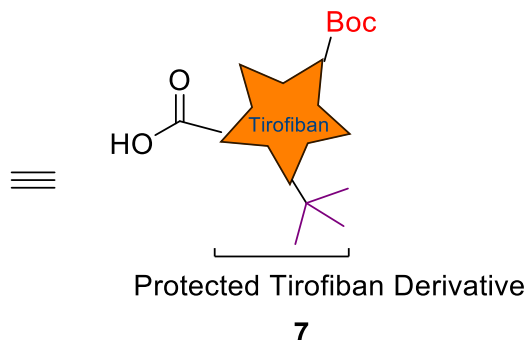

Scheme S4. Final labelling and deprotection

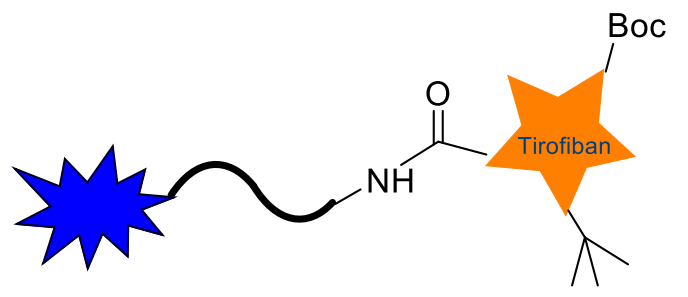

8

Synthesis of compound $8 . \quad \mathrm{N}, \mathrm{N}, \mathrm{N}^{\prime}, \mathrm{N}^{\prime}-$ tetramethyluronium hexafluorophosphate (HBTU) (38 $\mathrm{mg}, 0.1 \mathrm{mmol})$ was added to a solution of protected tirofiban derivative $7(66 \mathrm{mg}, 0.1 \mathrm{mmol})$ and triethylamine $(0.017 \mathrm{ml}, 0.125 \mathrm{mmol})$ in $5 \mathrm{~mL}$ dimethylformamide (DMF) at $0{ }^{\circ} \mathrm{C}$ under an argon atmosphere. After 5 mins of CyAl5.5-Namido-PEG 6 -amine $\mathbf{S} 7(129 \mathrm{mg}, 0.1 \mathrm{mmol})$ was added to the reaction mixture. The reaction was then allowed to proceed for $1 \mathrm{~h}$ at $0{ }^{\circ} \mathrm{C}$, followed by stirring overnight at rt. DMF was removed under vacuum. The crude product was purified by HPLC (gradient: $80 \%$ buffer A to $60 \%$ buffer A, $30 \mathrm{~min}$ ) to afford compound 8 as a dark blue oil. Yield, $54 \mathrm{mg}, 28 \%$. LRMSESI $[\mathrm{M}]^{+} \mathrm{m} / \mathrm{z}$ calcd. for $\left[\mathrm{C}_{94} \mathrm{H}_{131} \mathrm{~N}_{6} \mathrm{O}_{27} \mathrm{~S}_{5}\right]^{+} 1935.7$ found 1935.7. 


\section{Supporting Information}

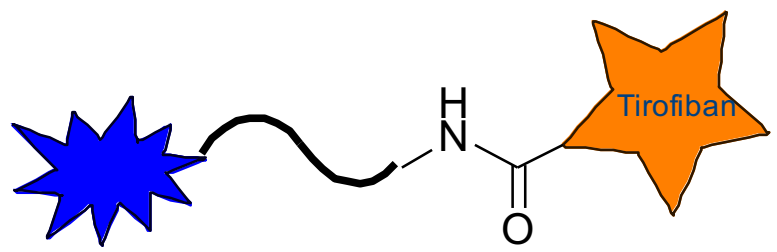

TIRO-CyAI5.5

Synthesis of CyAl5.5-N-amido-PEG6-

Tirofiban (TIRO-CyAl5.5). CyA15.5-Namido-PEG 6 -amine-tirofiban-Boc $\quad \mathbf{8} \quad(7.75$ $\mu \mathrm{mol}, 15 \mathrm{mg}, 0.5 \mathrm{mmol})$ was dissolved in a solution of TFA ( $2 \mathrm{~mL})$ in DCM $(2.5 \mathrm{~mL})$ at $0{ }^{\circ} \mathrm{C}$. The reaction was carried out under an argon atmosphere and proceeded for 6 hours. DCM and TFA were removed in vacuo, and the residue was dissolved in $0.5 \mathrm{ml}$ of buffer A and purified HPLC (gradient: $80 \%$ buffer A to $60 \%$ buffer A, $30 \mathrm{~min}$ ) to afford the product TIRO-CyAl5.5 as a dark blue sticky solid. Yield, 10 mg, 75\%. LRMS-ESI $[\mathrm{M}+\mathrm{H}]^{+} \mathrm{m} / \mathrm{z}$ calcd. for $\left[\mathrm{C}_{85} \mathrm{H}_{116} \mathrm{~N}_{6} \mathrm{O}_{25} \mathrm{~S}_{5}\right]^{+} 1780.6$, found 1780.8 .

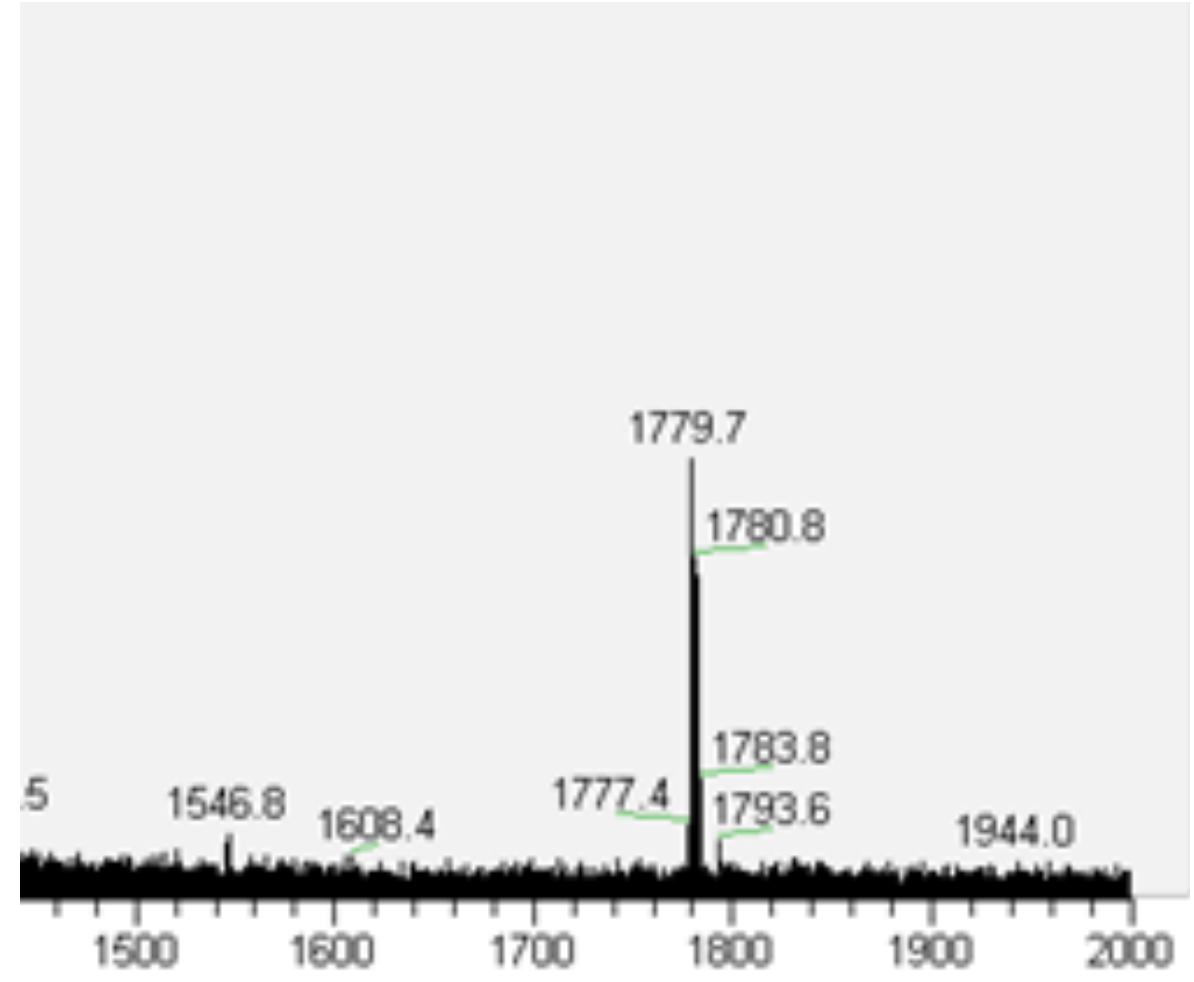

Figure S7. ESI-MS of TIRO-CyA15.5 
Supporting Information

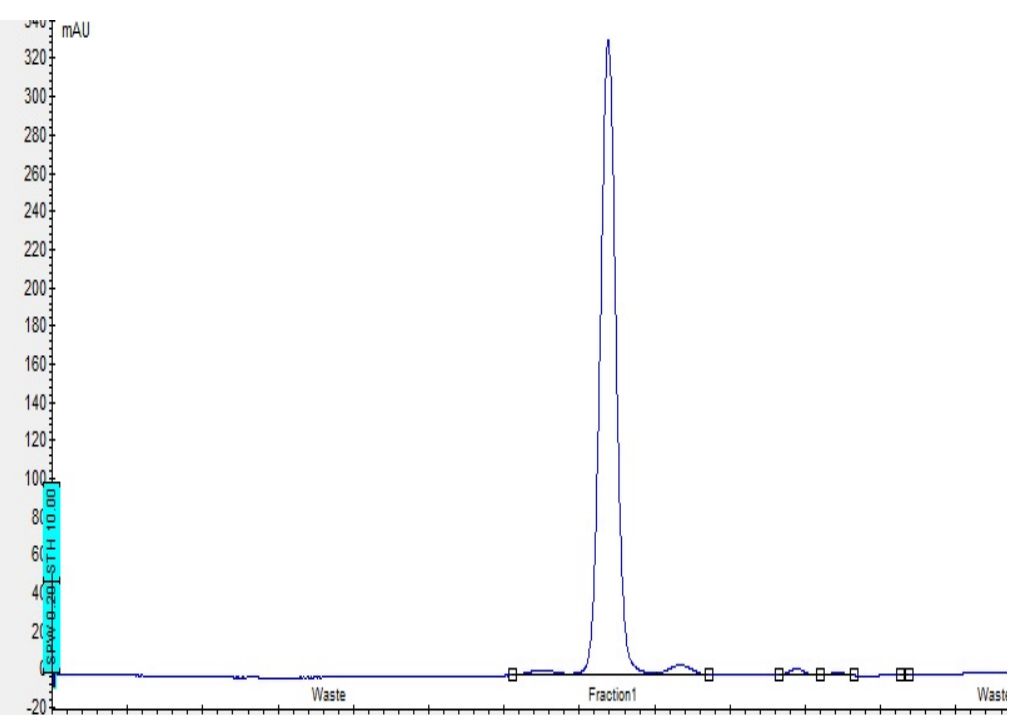

Figure S8. HPLC of TIRO-CyA15.5 


\section{Supporting Information}

NMR Spectra

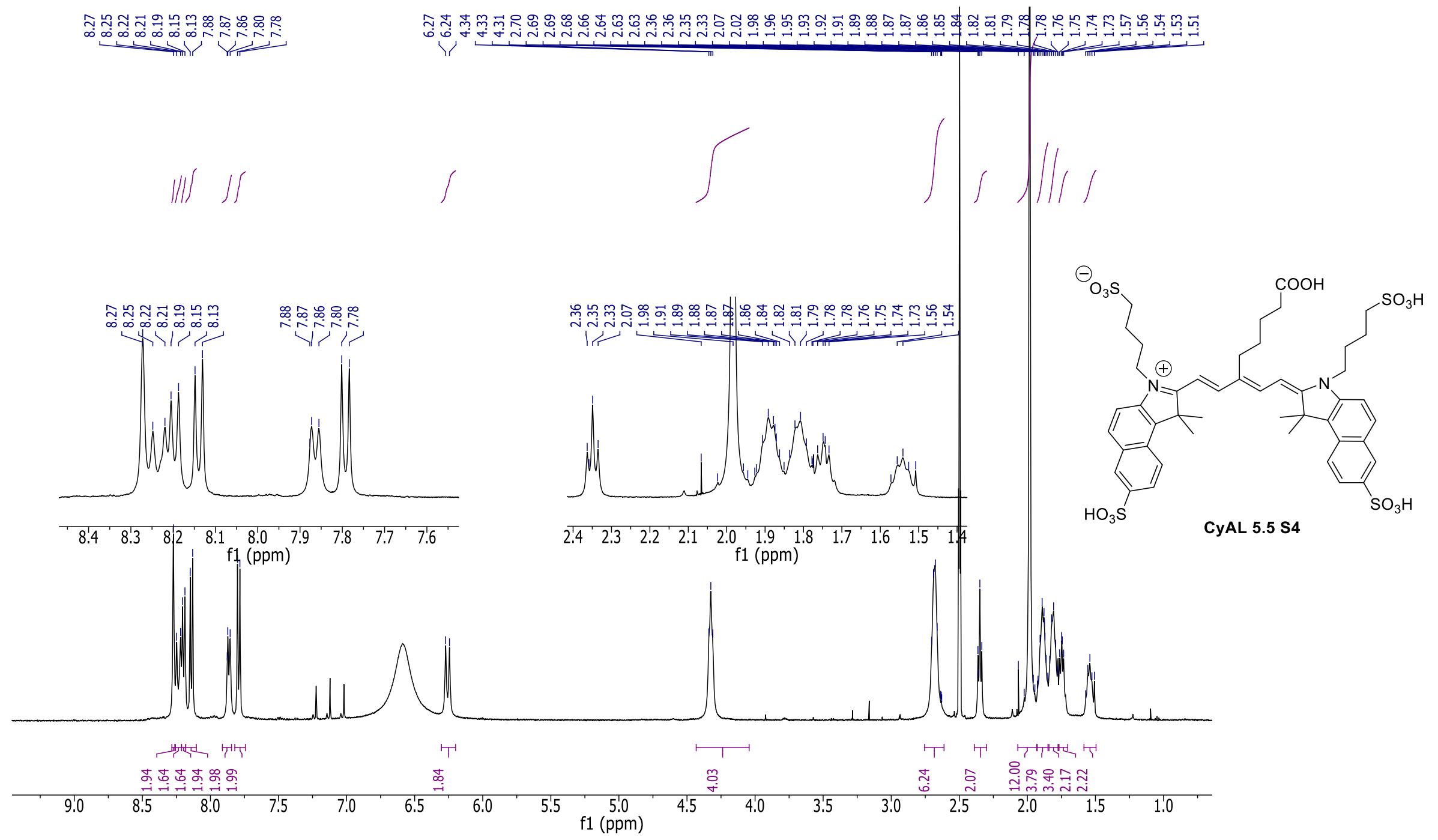

Figure S9. Proton NMR of CyA15.5 S4. 
Supporting Information
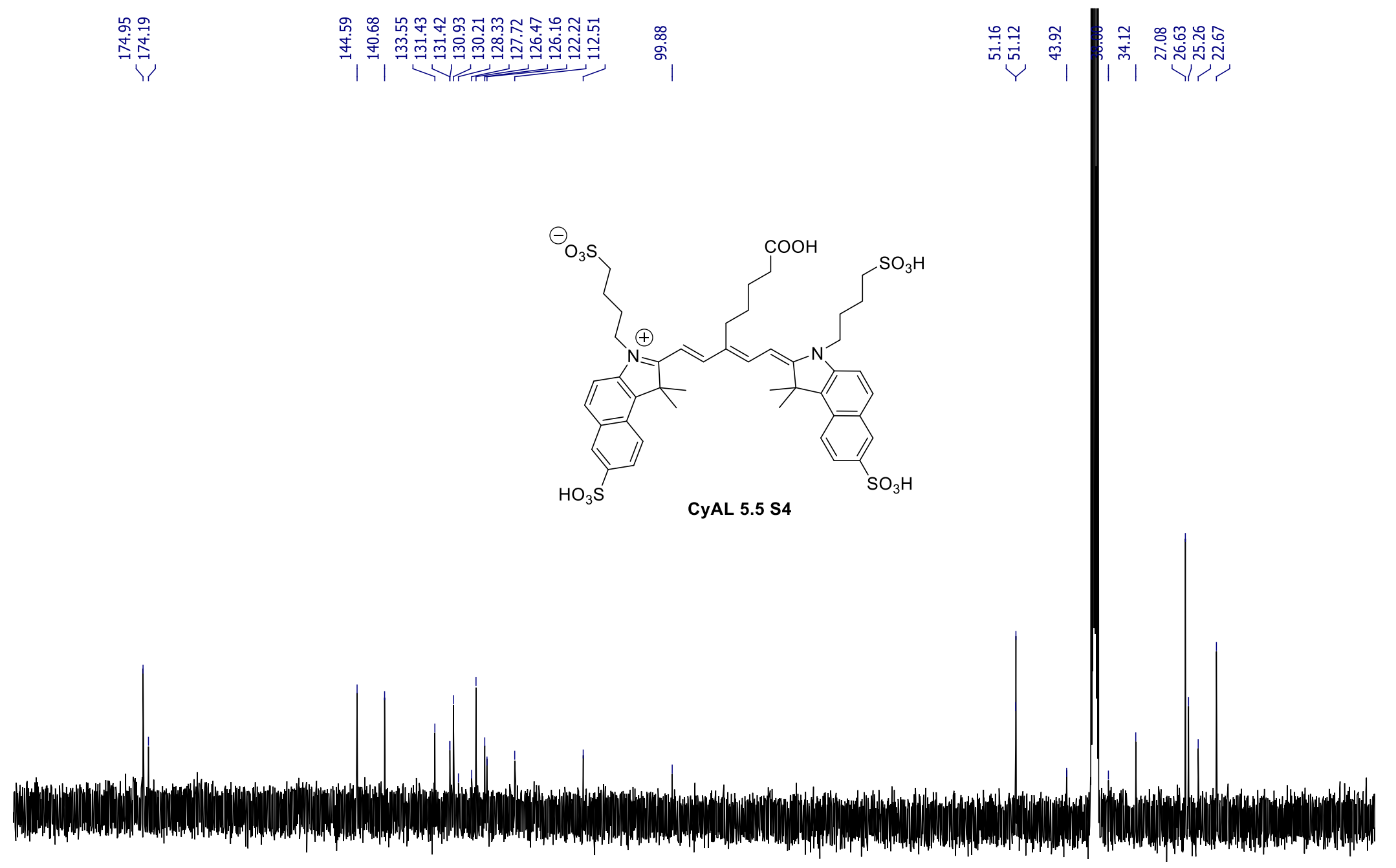

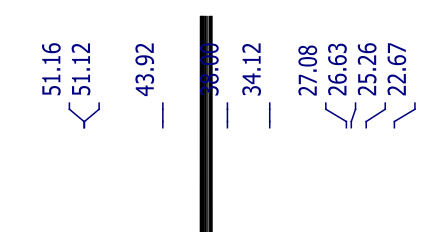

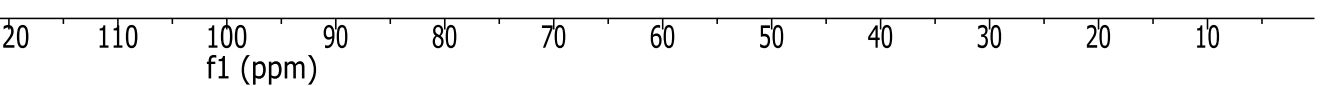

Figure S10. Carbon NMR of CyA15.5 S4. 
Supporting Information
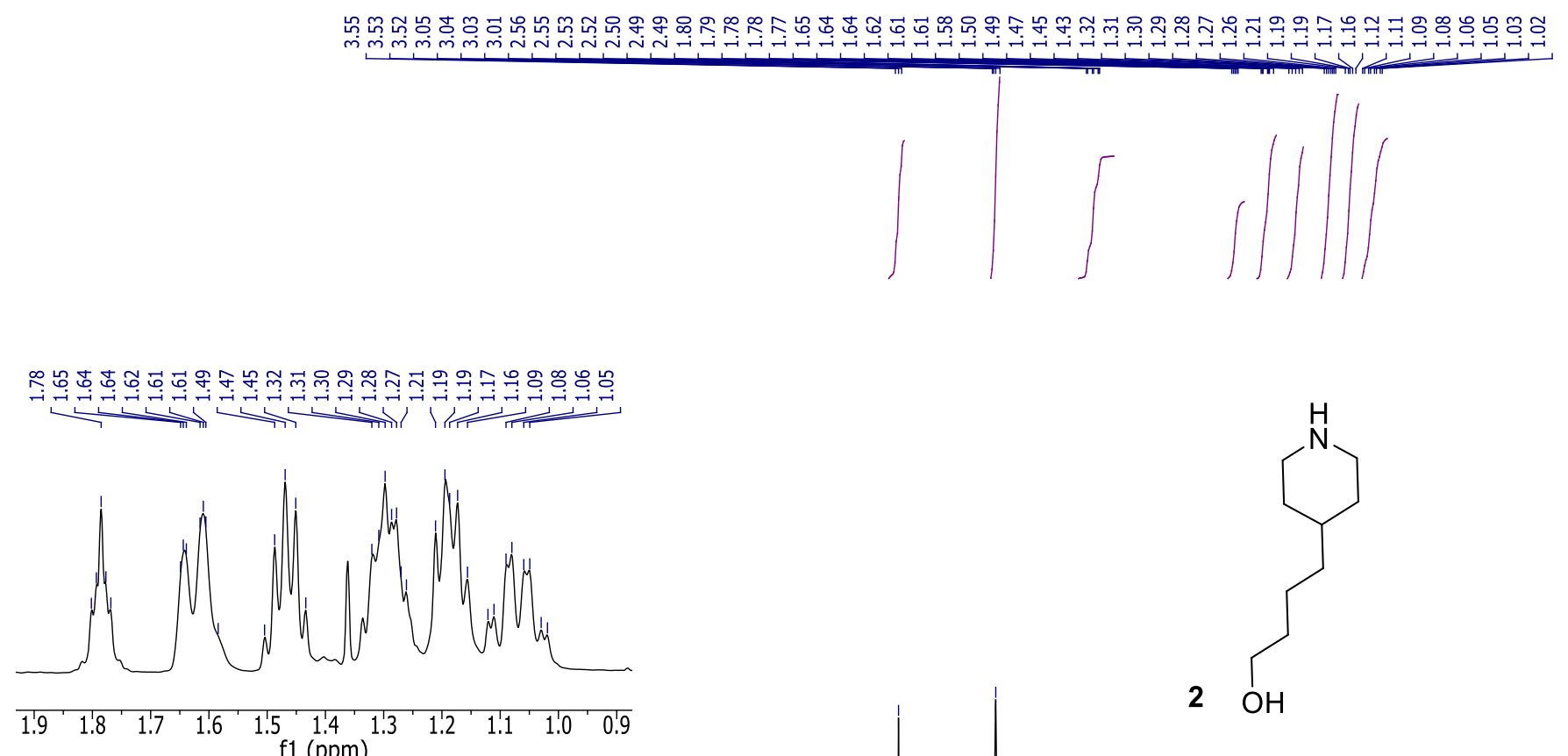

$2 \mathrm{OH}$

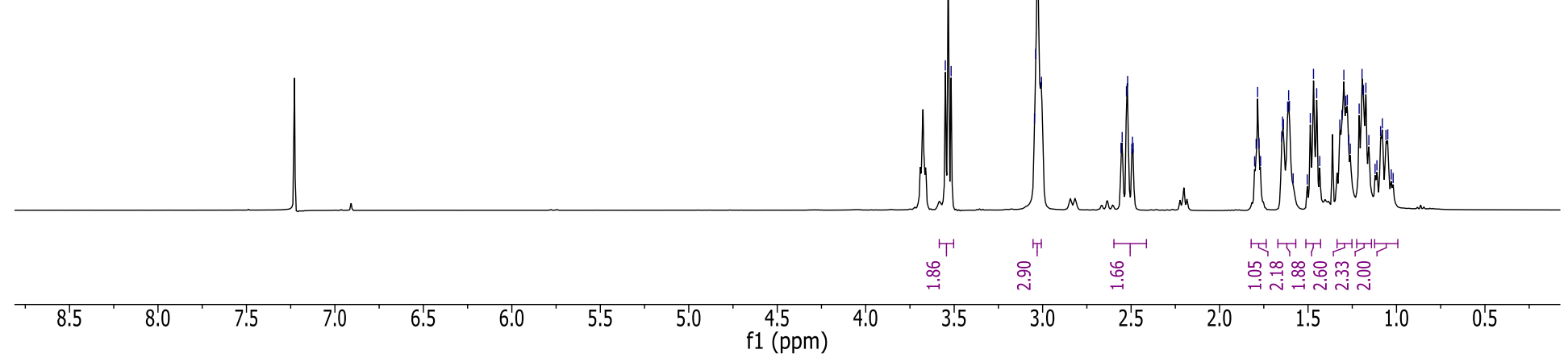

Figure S11. Proton NMR of compound 2 


\section{Supporting Information}

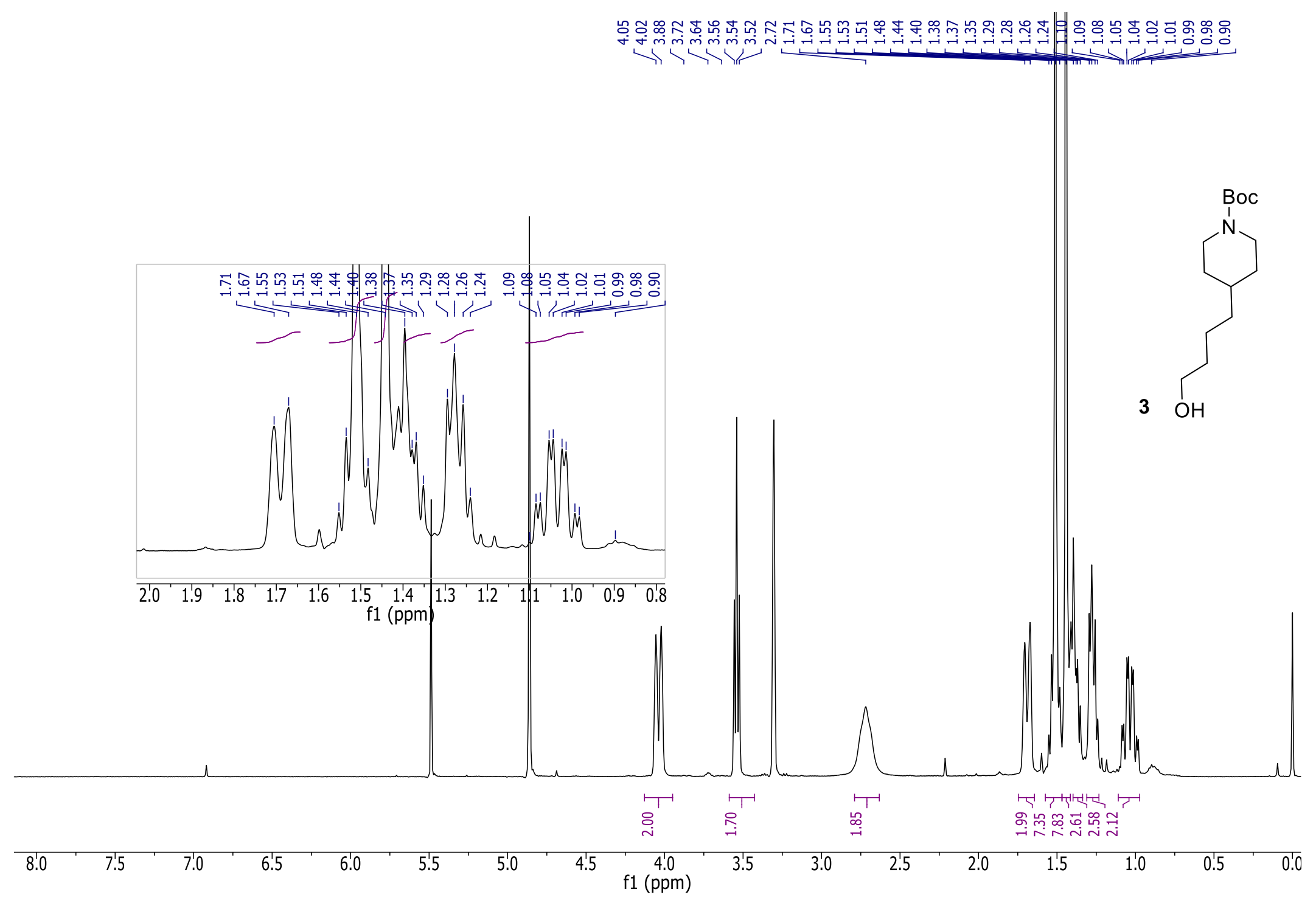

Figure S12. Proton NMR of compound 3 
Supporting Information

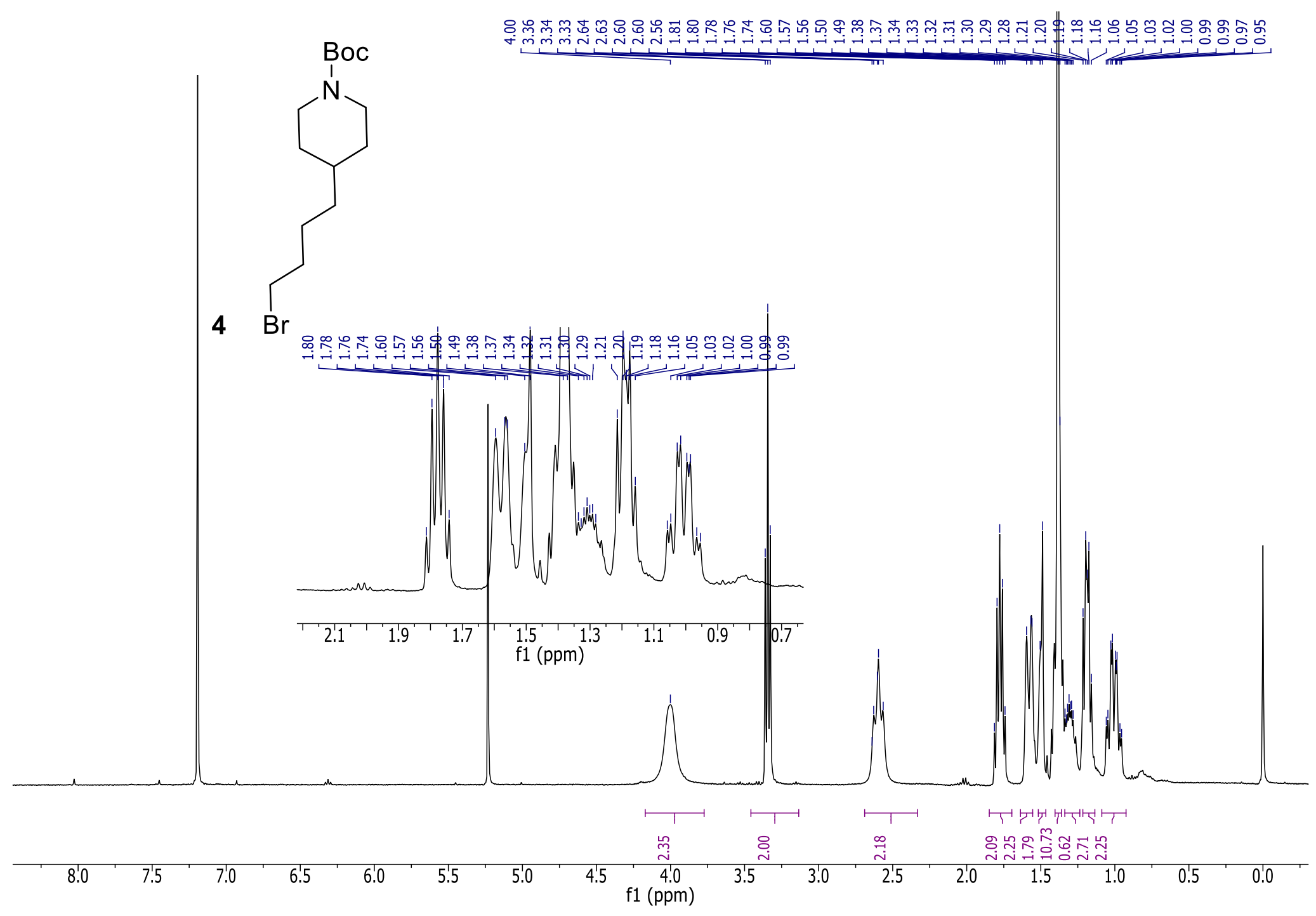

Figure S13. Proton NMR of compound 4 


\section{Supporting Information}

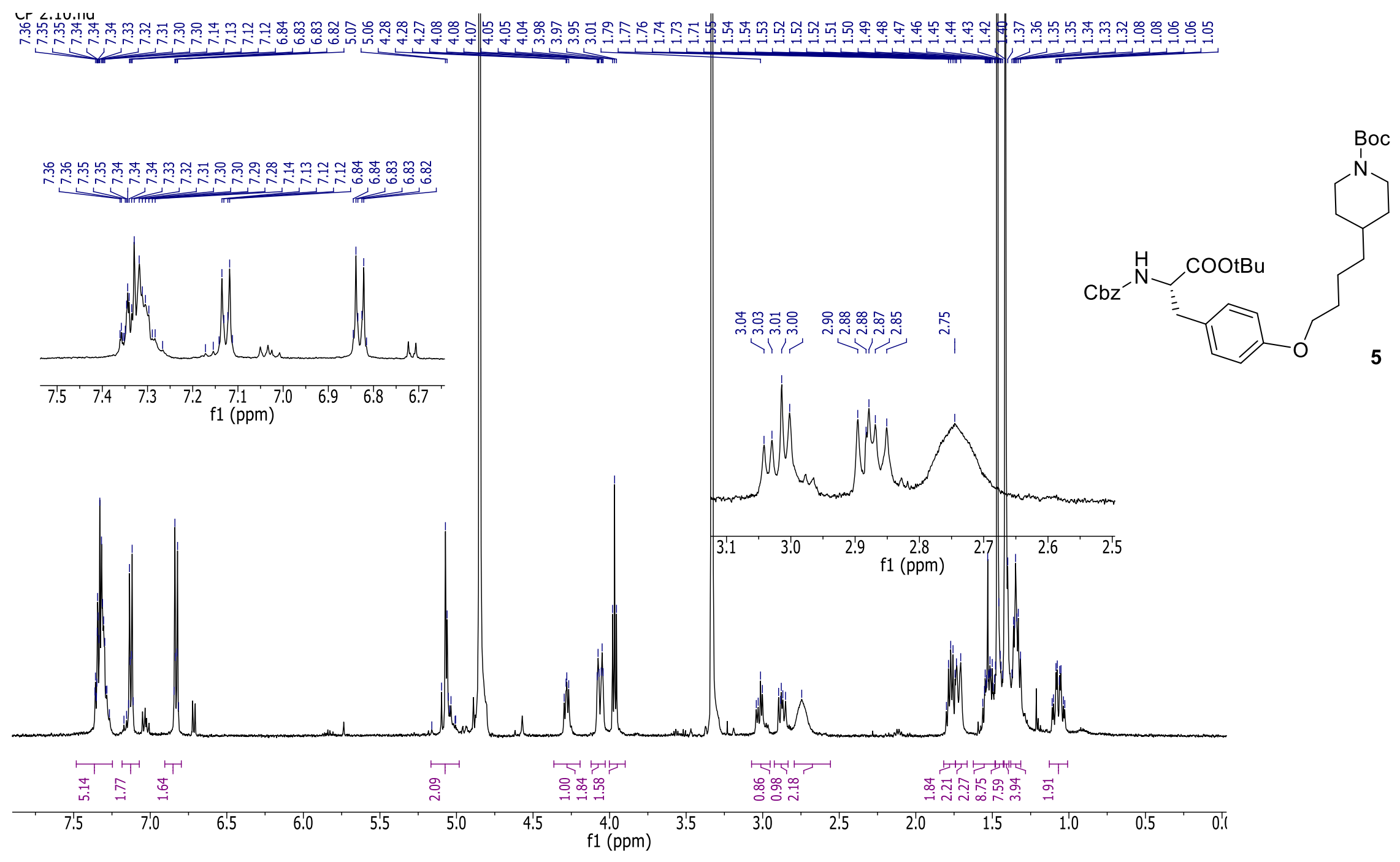

Figure S14. Proton NMR of compound 5 
Supporting Information

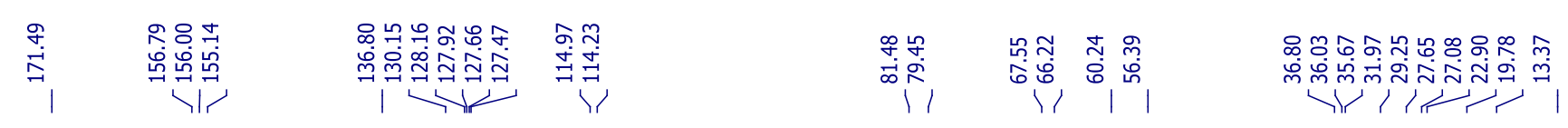

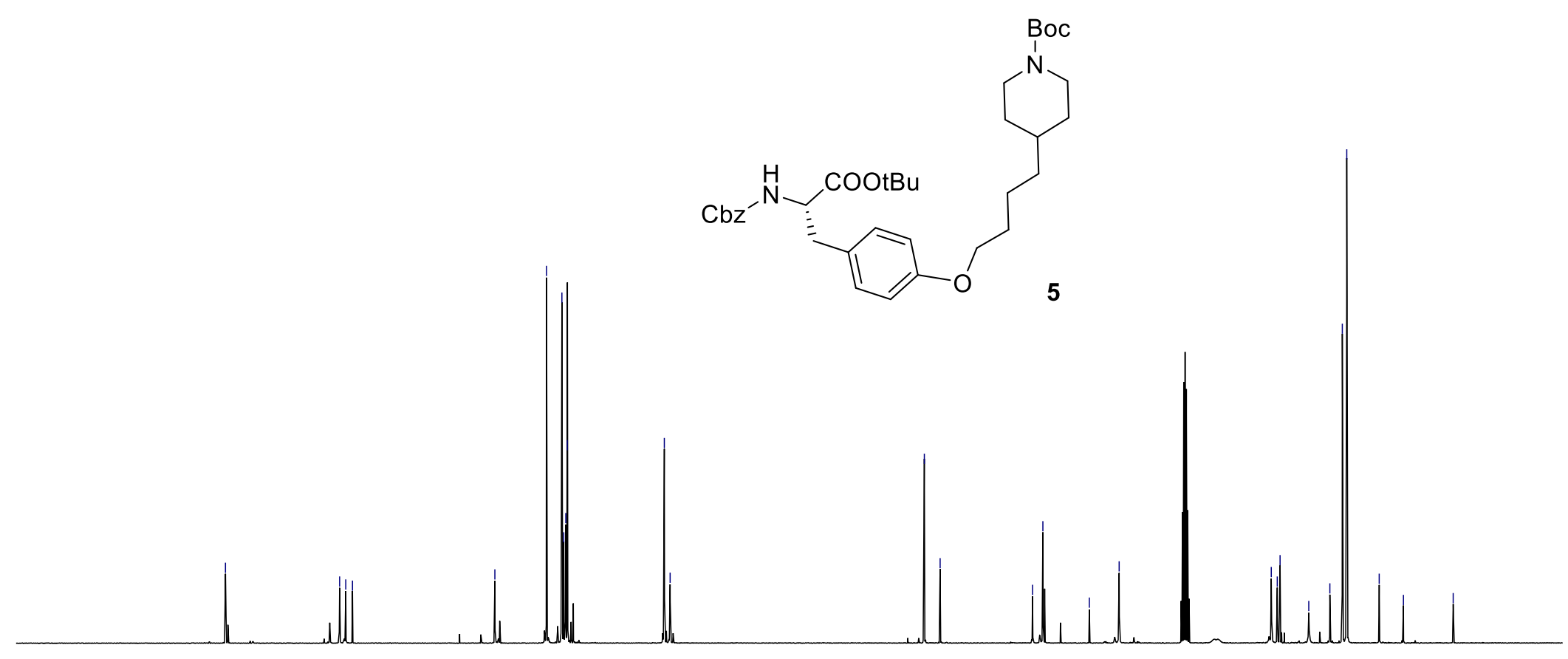

\begin{tabular}{rlllllllllllllllllll}
\hline 190 & 180 & 170 & 160 & 150 & 140 & 130 & 120 & 110 & $\begin{array}{c}100 \\
\mathrm{f1}(\mathrm{ppm})\end{array}$ & 90 & 80 & 70 & 60 & 50 & 40 & 30 & 20 & 10 & 0
\end{tabular}

Figure S15. Carbon NMR of compound 5 


\section{Supporting Information}

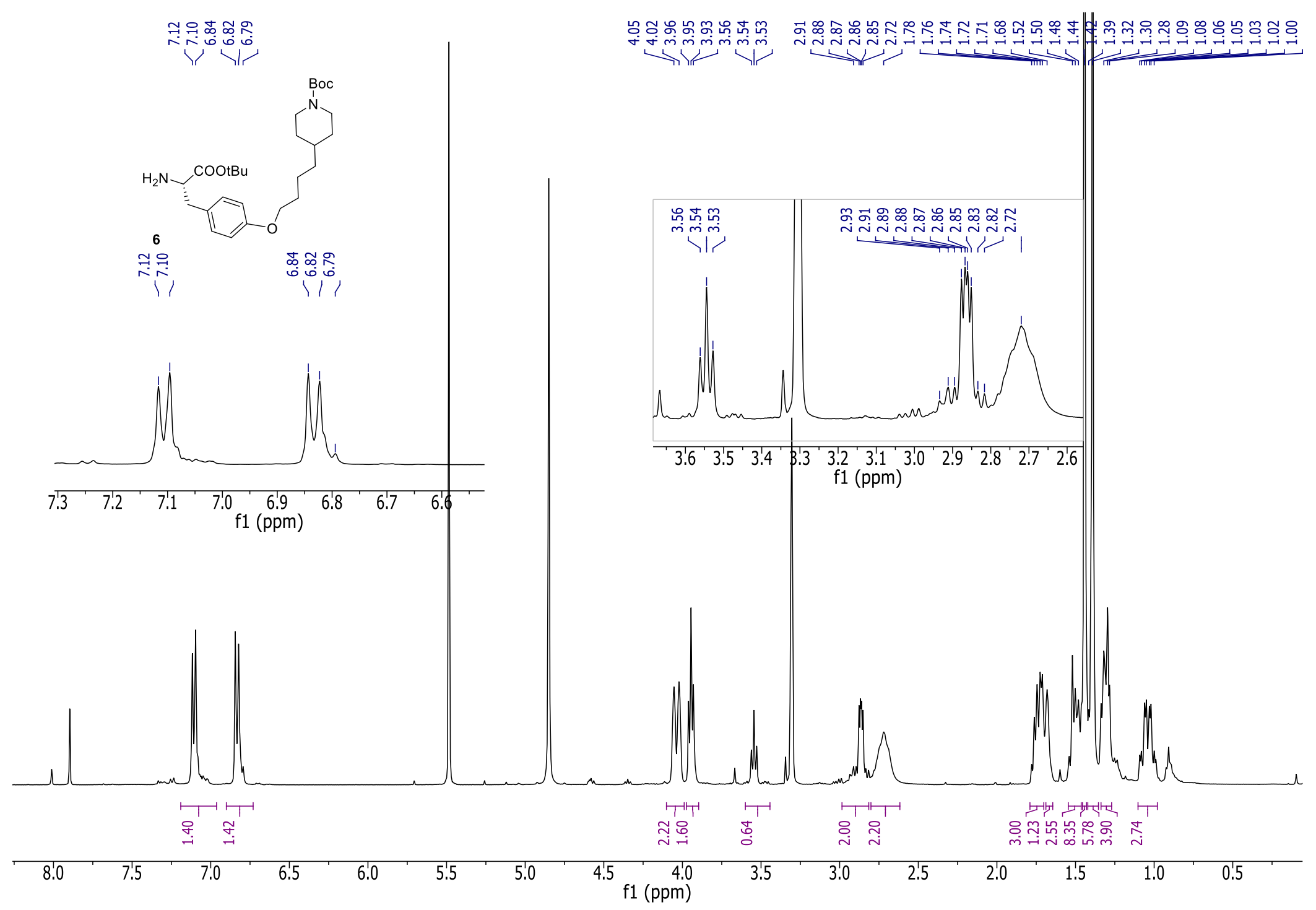

Figure S16. Proton NMR of compound 6 
Supporting Information
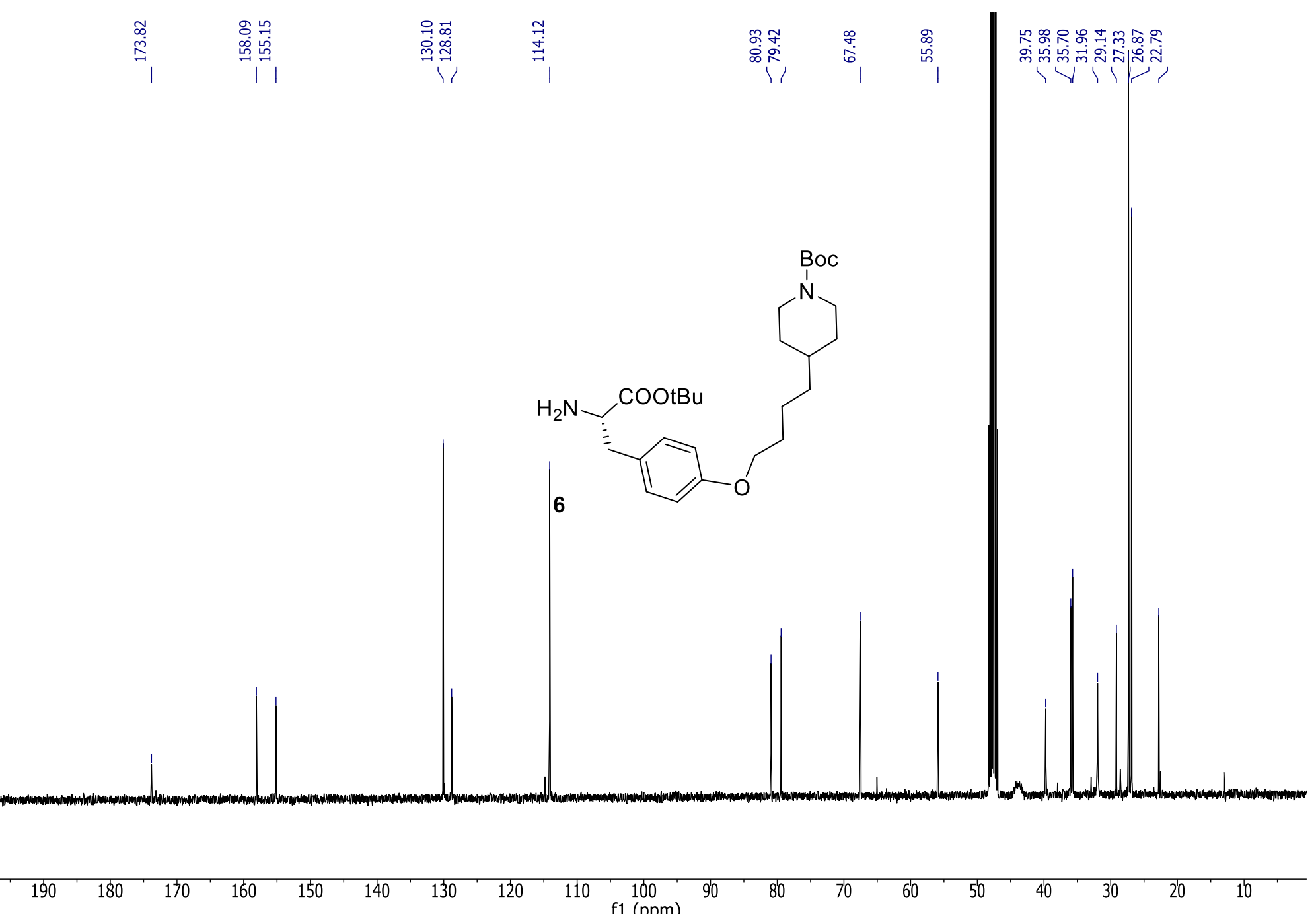

Figure S17. Proton NMR of compound 6 
Supporting Information

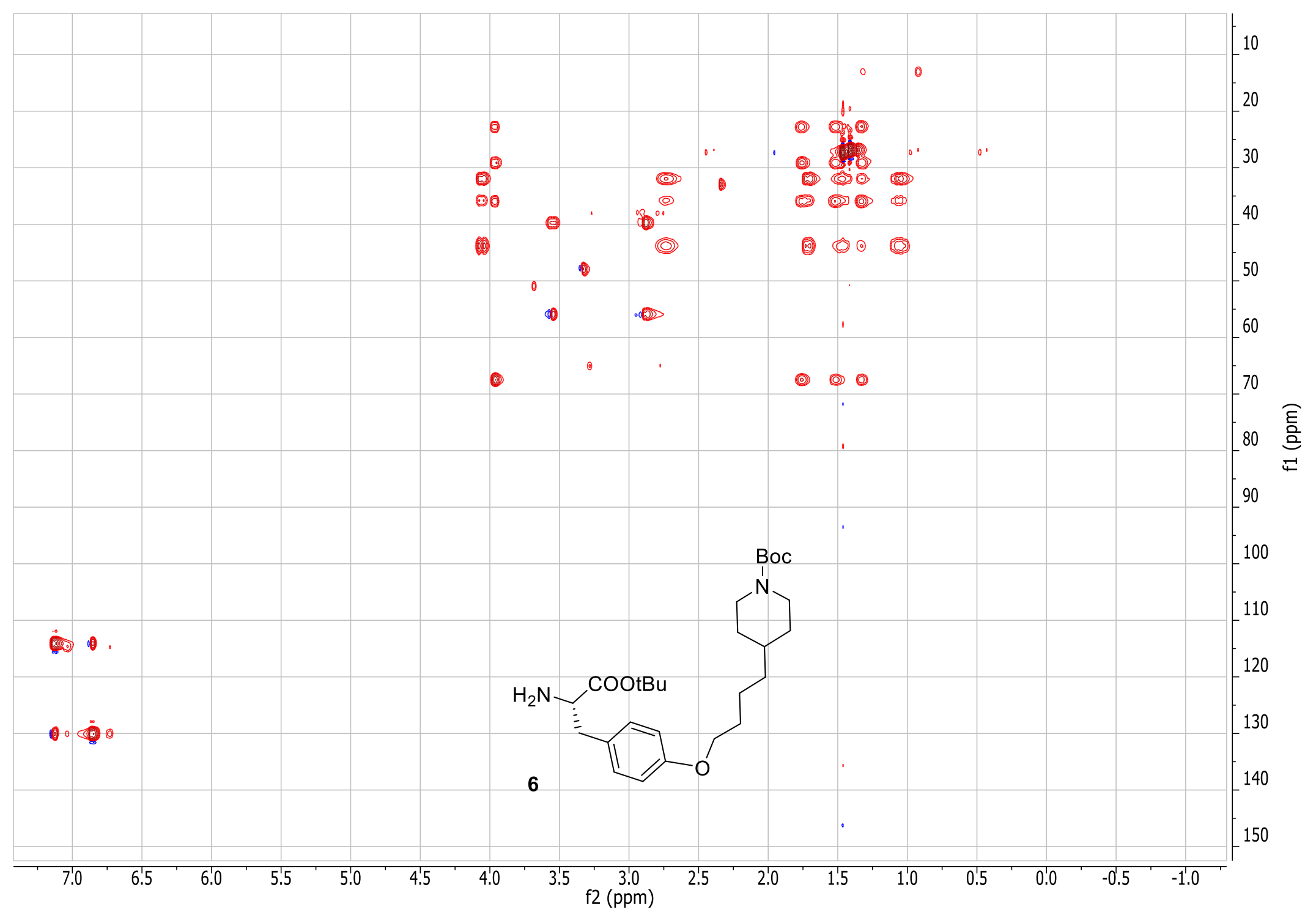

Figure S18. COSY NMR of compound 6 
Supporting Information

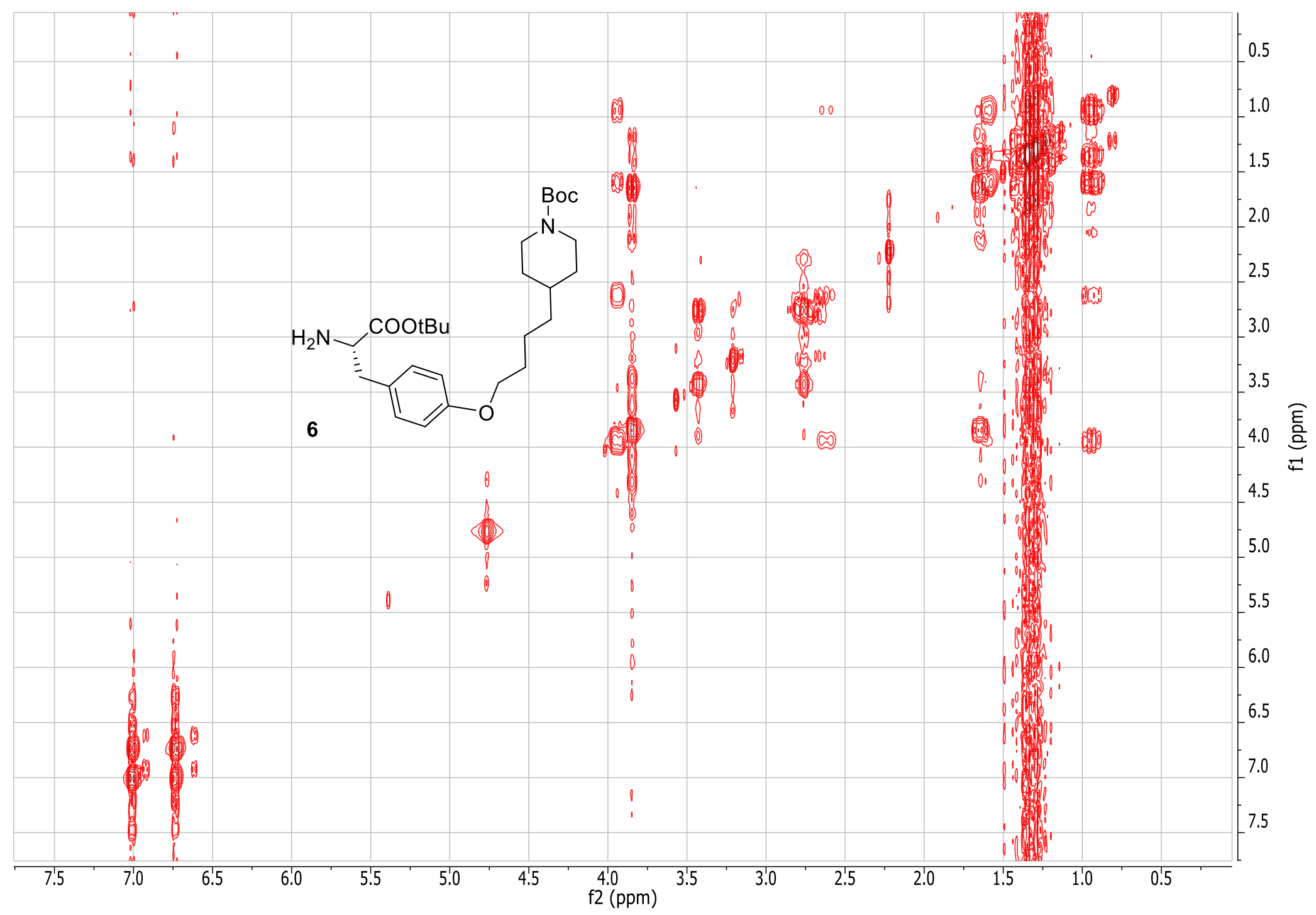

Figure S19. ROSY NMR of compound 6 
Supporting Information

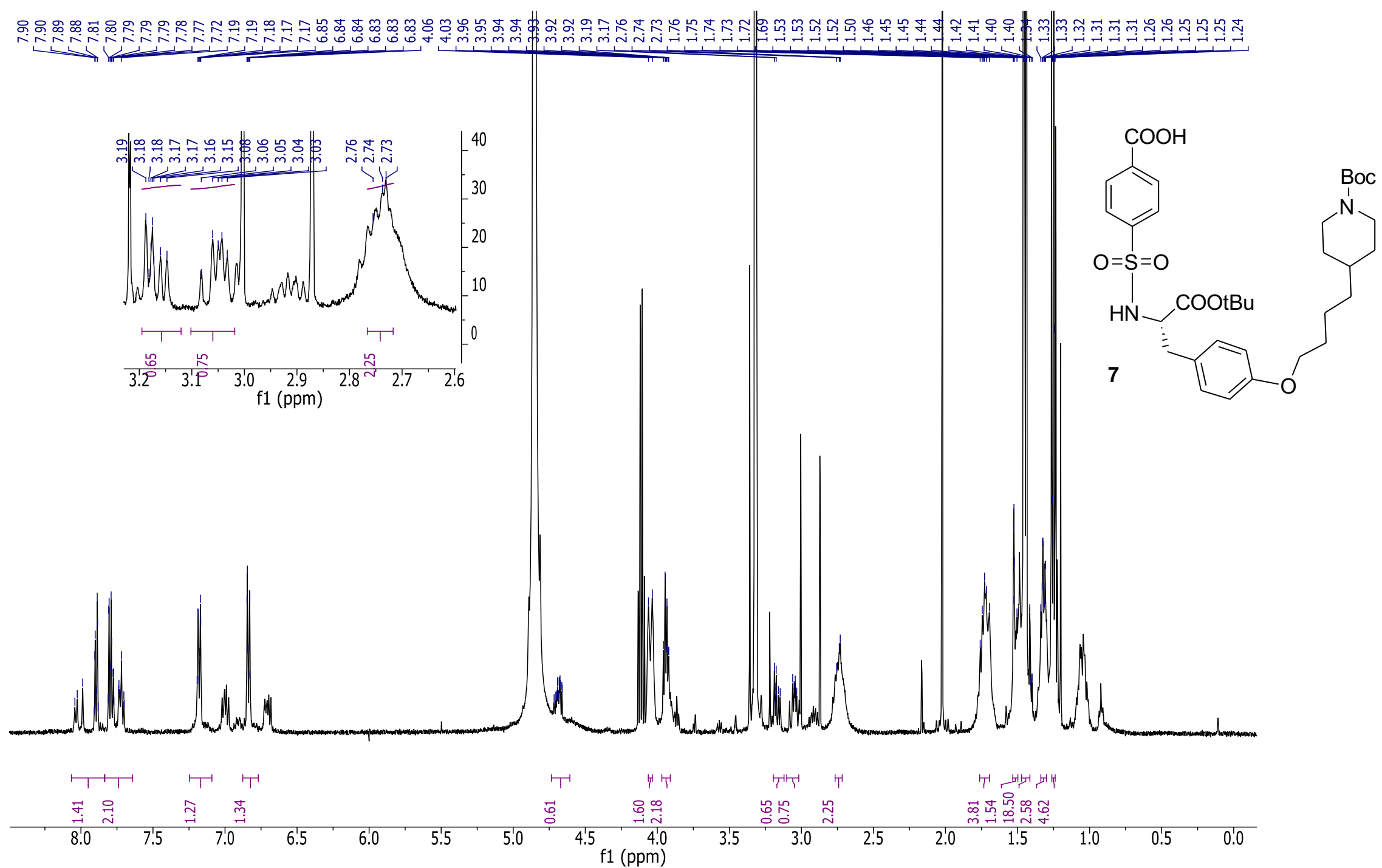

Figure S20. Proton NMR of compound 7 
Supporting Information
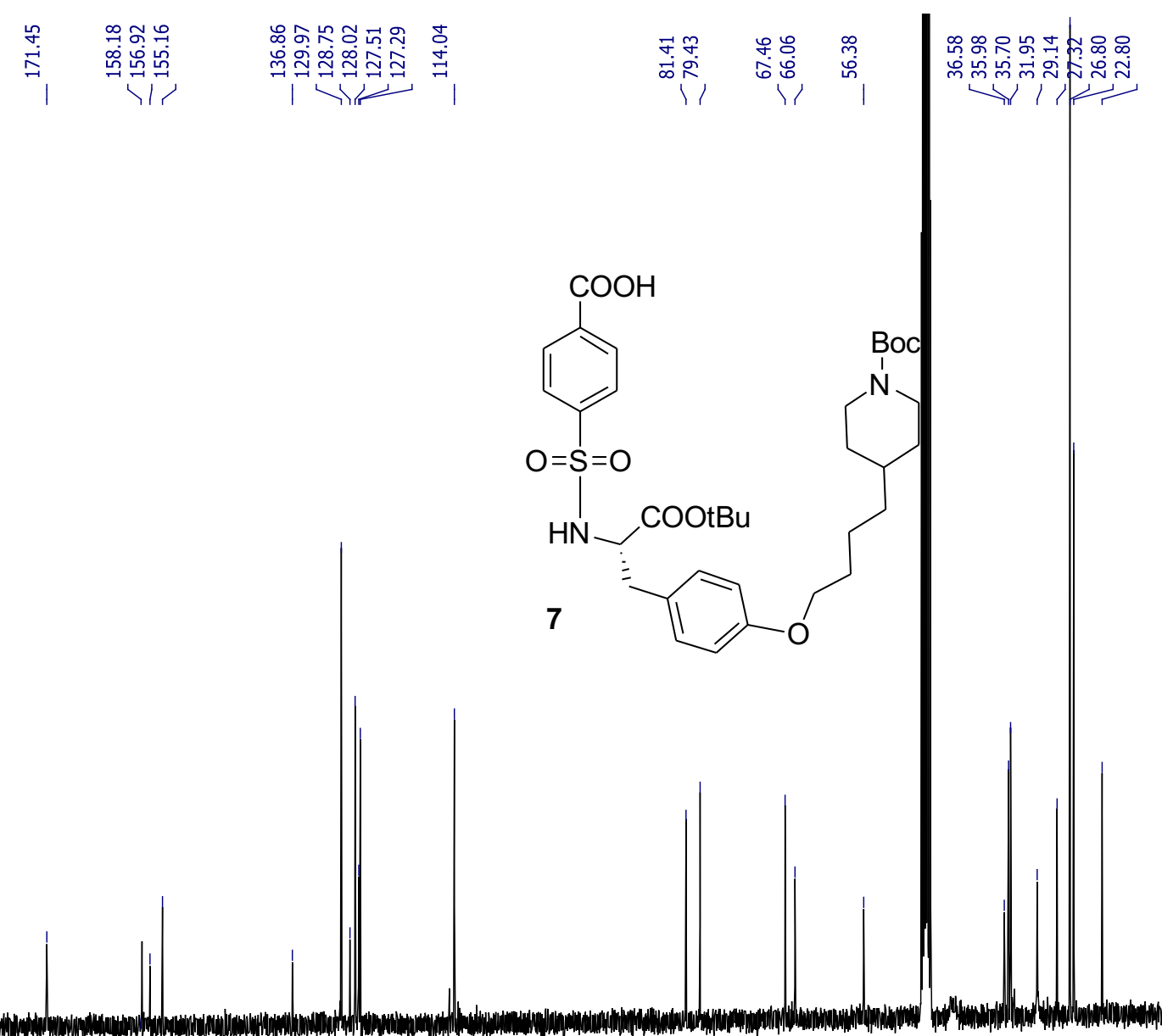

$\begin{array}{lllllll}210 & 200 & 190 & 180 & 170 & 160 & 150\end{array}$

$140 \quad 130 \quad 120$

100
f1 (ppm)

80

60

$30 \quad 20$

10

Figure S21. Carbon NMR of compound 7 
Supporting Information

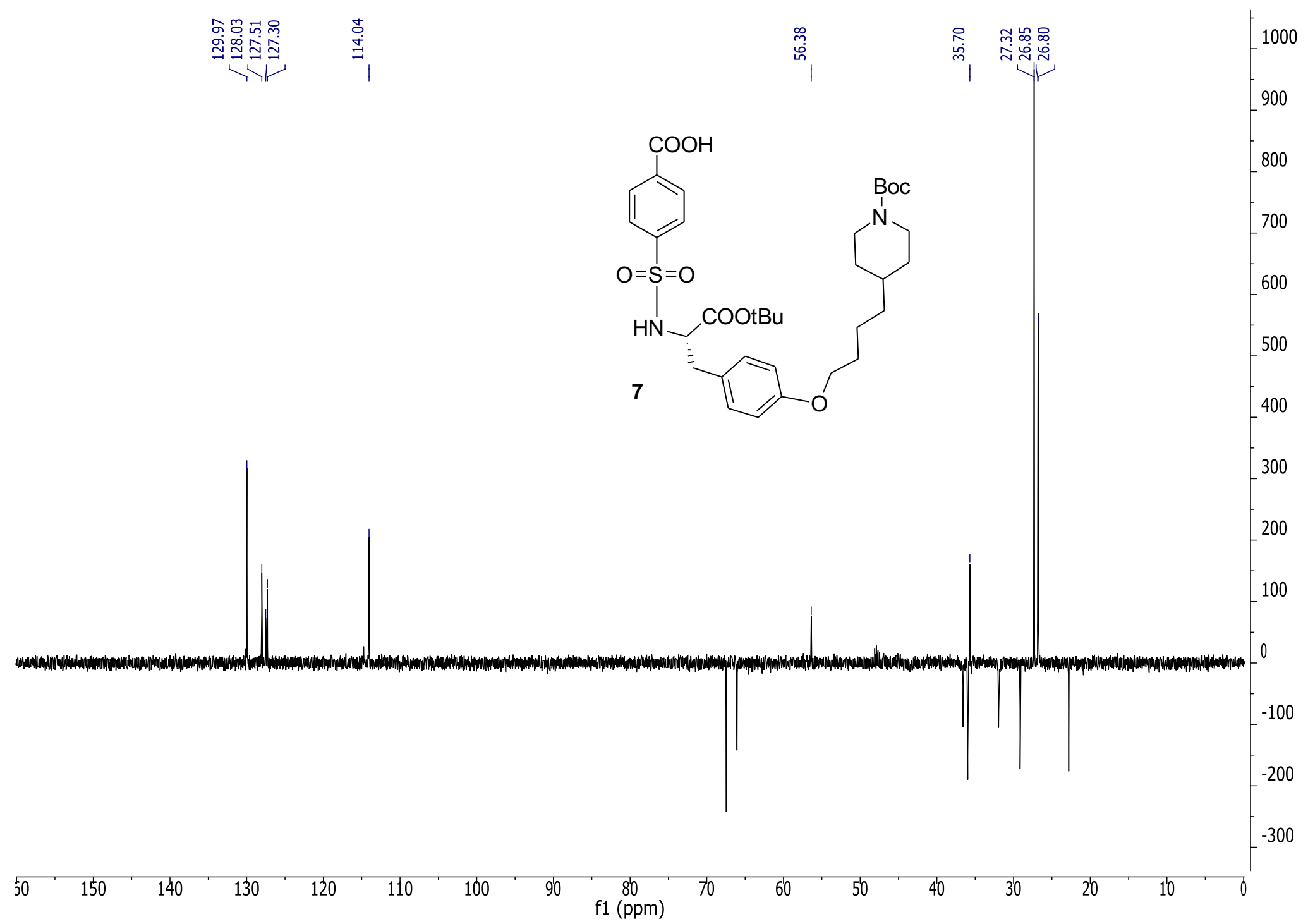

Figure S22. DEPT Carbon NMR of compound 7 